\title{
Egyed Ákos
}

\section{Kossuth Lajos és Erdély 1848-ban}

Kossuth Lajos a 19. század igazi gyermeke, s kora történelmének egyik legjelentösebb alakítója volt. Elsösorban a magyar történelemé, de a Közép- és Közép-Kelet Európa országaiban bekövetkezett változások is nehezen volnának értelmezhetöek Kossuth politikájának és szerepének figyelmen kívül hagyásával. És akkor még nem szóltunk arról, hogy Nyugat-Európában, söt az Észak-Amerikai Egyesült Államokban is számon tartották, a közvélemény nagyra becsülte, s a 21 . század elején is ö világszerte a legismertebb magyar politikus.

Kossuth a 19. század gyermeke volt a szó legszorosabb értelmében is: 1802 . szeptember 19.-én született a Zemplén megyei Monokon, s 1894. március 20.-án hunyt el Torinóban. Kis híján átélte a sok változást hozó századot.

Kossuth politikai nagyságának magyarázatát mindenekelött abban látjuk, hogy már fiatalon felmérte az európai történelem mozgásirányát $s$ ezzel összhangban alakította ki eszméit és felfogását. Szilárdan hitt az emberi nem tökéletesítésének a lehetöségében, s hogy a haladás - bár útja lehet zeg-zúgos - feltartóztathatatlan.

Ha arra a kérdésre keressük a választ, hogy miért lehetett Kossuth Lajos az ugyan nagyon régi nemesi származású, de vagyontalan vidéki ügyvéd gyermeke a magyar nemzet meghatározó vezetője a sorsfordító 1848-1849-es években, egy olyan nemzeté, amelyben századok óta a gazdag fönemesség, az arisztokrácia állt az élen, nos erre a kérdésre azt válaszolhatjuk, hogy nagy tehetségén és lankadatlan szorgalmán túl azért emelkedett pályaíve oly magasra, mert ö tudta nagy kortársai között is a legjobban képviselni és megjeleníteni a magyarság reális törekvéseit és álmait. Ezeknek a törekvéseknek és vágyaknak a hajszálgyökerei történelmünknek régebbi, dicsőbb korából táplálkoztak, de a későbbi hanyatlás századainak szenvedései alakították át a vágyakat a ,haza és haladảs” jelszavát hirdető reformmozgalommá, azt pedig békés forradalommá, s aztản - mert egy adott pillanatban nem volt más kiút -, hatalmas szabadságharccá.

Kossuth hitt Európa jövőjẻben, mert Európa fejlettebb régióinak és az ÉszakAmerikai Egyesült Államoknak gazdaságát és civilizációját modell-értékünek fogadta el. Rendületlenül bízott abban is, hogy a magyarságnak, Magyarországnak kedvezöbb, múltjához méltóbb helyet lehet biztosítani a fejlett nemzetek között. Erröl a következőket vallotta: „Helyünket, melyet az európai társadalomban mint annak integráns részét történelmünkkel elfoglaltunk, csak úgy tarthatjuk meg, ha a kor vezéreszméje által kijelölt tevékenység ojtványágát történelmi fejleményü nemzeti jellemünk élő fảjảba oltjuk."I

Kossuth eszmerendszere egyidöben alakult ki s nagyrészt megegyezett a reformkori nagy kortársak: Széchenyi István, Deák Ferenc, Kölcsey Ferenc s nem utolsósorban Wesselényi Miklós koncepciójával, de az 1840-es években a „liberális táboron belül” a „mérsékeltebb" irányzattal szemben, a radikálisabb irányvétel vezéralakja lett, és ebben Wesselényi is vele tartott. Amint egyik elismert kutatója, Pajkossy Gábor írja: „Felismerte, hogy önkorlátozása csak félmegoldásokat szül, másfelöl nemzedéke nem fogja megkapni a tíz-tizenöt évet, amelyre a kortársak a reformprogram megvalósításának idöigényét becsullték."2 Nem látta semmi jelét annak, hogy a Habsburg-hatalom hajlandó lenne

\footnotetext{
${ }^{1}$ Kossuth Lajos: Iratai. $L X$. Szerk. Kossuth Ferenc, Budapest, 1902. 230

2 ".Nemzeti újjászületés". Válogatás Kossuth Lajos írásaiból és beszédeiböl. Szerk. Pajkossy Gábor, Budapest, 2002. Utószó: 232
} 
megváltoztatni a Magyarország iránti, mintegy másfél százados, eléggé merev politikai kurzusát, amely a magyar reformmozgalom ambíciós programja, s különösen Magyarorszảg önállósulási törekvései iránt ellenséges volt.

A magyar nemzeti mozgalom vezetőinek nem volt könnyủ dolguk, mert egyszerre kellett megvívniuk harcukat a Habsburg-hatalom és a vele szövetkezett hazai konzervativ erök ellen céljaik megvalósitásáért. Abban nem volt közöttük jelentős nézetkülönbség, hogy Magyarországnak önállóvá kell válnia, s a társadalmat ki kell szabadítani a sok százados elavult rendi-feudális világ kötöttségeiböl, s szabaddá kell tenni az utat a polgárosodás elött. A hogyan kérdésben viszont erös ellentétek osztották meg a magyar reformmozgalmat. A reformokat kitervelő és elinditó Széchenyi István gróf inkább támaszkodott volna a Habsburg államra és a magyar fónemességre az elmaradott magyar gazdaság és a társadalom modernizációja, s a magyar államiság önállósodása ügyében, de vẻgül is csalódnia kellett: a Habsburg-hatalom nem volt hajlandó lényeges engedményekre, továbbra is ragaszkodott Bécs irányitó szerepéhez, Magyarország erös központi függöségének fenntartásához, a régi állami s társadalmi rendszer majdhogy változatlan megőrzéséhez.

Kossuth politikája azért volt más, mint a Széchényiẻ, mert a magyar nemzet belsô eröinek kibontakoztatásával vélte elérni a nagy nemzeti célokat. Sikereit annak köszönhette, hogy képes volt megszólítani minden társadalmi erőt, képes volt a reformkor alapvető társadalompolitikai jelszavának, az érdekegyesítésnek tömeges támogatást biztosítani. ${ }^{3}$

Kossuth volt a jobbágyfelszabadítás legkövetkezetesebb előkészítője, aztán megvalósítója, s az alkotmányos szabadságjogoknak az eddigi jogtalanokra való kiterjesztője. Visszaemlékezve az 1848-as átalakulásokra ezeket írta: „És valóban a javításokat, melyeket keresztülvittünk, két elvre lehet visszavezetni. Az egyik elv: igazsảg a népnek - a másik: biztositás az alkotmánynak. E második jogunk volt, àz első kötelességünk." 4

Kossuth politikusi nagysága abban is megnyilvánult, hogy meg tudta szólitani a jobbágytartó nemességet is; ő a jobbágyfelszabaditással nem akarta koldussả tenni, kiirtani az eddigi vezetố társadalmi rendet, ti. a nemességet - mint például a nagy francia forradalom vagy a 20. századi Közép- és Kelet-Európában a szocialista, kommunista rendszerek - hanem állami kártéritéssel lehetőséget kínảlt számára a fennmaradảshoz és érvényesüléshez. $\mathrm{Az}$ érdekegyesítés jelszava nem maradt hát üres szónoki jelszó politizálásának eszköztárában, hanem gyakorlati jelentőséget kapott vezetői gyakorlatában.

Kossuth már a reformkorban polgári magyar nemzetben gondolkodott: a polgárosítás érdekében végre kellett hajtani a szükséges társadalmi reformokat, s a nemzeti célok megvalósítása érdekében helyre kellett állítani az ország területi egységét. Következésképpen Kossuth figyelmét Erdély nem kerülhette el.

\section{Kossuth Erdély-politikájának kialakulása}

Kossuth Lajos Erdély-politikájának elméletét a reformkorban alakította ki, s az 18481849-es forradalom és szābaadságharc idejẻn került sor gyakorlati megvalósítására, hogy aztán a 19. század második felében bizonyos mértékig módosuljon a közben szerzett tapasztalatok következtében. Kossuth az említett hảrom korszakban más-más egyẻni pozícióban volt; koronként egymástól nagyon is eltérő szerepet osztott ki számára a

\footnotetext{
${ }^{3}$ Vö. Szabad György: Kossuth irányadása. Történelmet formáló tettek l. fejezet. Budapest, 2002. 104134.

${ }^{4}$ Kossuth Lajos: Irataim az emigrációból II, Budapest, 1881. 165. 
történelem: 1848 elött a magyarországi reformellenzék egyik meghatározó egyénisége, a forradalom idején pénzügyminiszter és hadszervező, 1848 szeptemberétöl a szabadságharc vezetöje, az emigrációban különböző nem hivatalos szövetségekben egyszerüen politikai menekültként volt Magyarország fúggetlenségi ügyének következetes képviselője. Nem lett volna igazi politikus, ha álláspontját időnként nem módosítja - elvei feladása nélkül - a különbözö történelmi korszakok változó viszonyai szerint.

Kossuth Lajosnak a reformkorban kialakuló Erdély-politikája európai indíttatású volt. Ö korán felismerte kontinensünk történeti mozgásirányát, amely a polgári nemzetek születése és a nemzeti egység, a saját független államok létrehozása irányába mutatott.

Az 1830-as évek elején a magyar politikusok körében mind gyakrabban vetődött fel Magyarország és Erdély újraegyesítése. Kossuth az elsők között foglalt állást ebben a kérdésben, a Wesselényi Miklóshoz 1833. szeptember elsején keltezett levelében. Hírek szerint - írta Kossuth - Erdély országgyúlésére a kormány olyan regalisták meghívását tervezi, akik az unió ellenzői, velük szeretne megszavaztatni egy olyan határozatot, hogy Erdély egyesülni nem kíván. Ennek megakadályozására ajánlja - miután erre szólította fel „egy úr, kívánatos titokban”: - „Igyekezzék magát Nagyságod követté választatni, mert minden igaz magyarnak, ki a két testvér haza egyesültében nemzetünkre új szép hajnal virradtát várja, Nagysádba van vetve reménye s Nagyságod és baráti azon »keble«, melyhez mint a tüzimádók a naphoz fordulunk, midőn a két testvér haza egyesületéért fohászkodunk."5 Kossuth leveléböl kiderül, hogy Wesselényi körében téma volt az unió, s hogy erről a bontakozó magyarországi reformellenzéknek is tudomása volt. Kossuth, aki egyre nagyobb befolyásra tett szert a magyar politikai közvélemény formálásában mint az Országgyülési Tudósítások szerkesztője, a két haza egyesülésétöl „szép hajnal virradtát” várta. Aztán hosszú ideig nem foglalkozott Erdéllyel, aminek okai közt politikai perét és fogságát kell elsősorban gyanitanunk. Kiszabadulása után azonban néhány alkalommal részletesen írt Erdélyröl és az unióról.

A Pesti Hirlap 1841. április 14-i számában Erdély és az Unió - egység a magyarnak címü cikkében elöszöris megvallotta, hogy Magyarországon alig ismerik Erdélyt. és fordítva: az erdélyiek sem sokat tudnak a magyarországi viszonyokról. $\mathrm{O}$ azonban - mégha esetleg téved is egyben-másban - szükségesnek tartja nézeteinek kifejtését.

A nemzeti egység megvalósítására való törekvés európai jelenség, ,világerővel” hat. Az egységtörekvés természetes dolog, mert a nemzeteknek egyediségük van, mint az embernek, emellett történelmi indíttatású jelenség, mert Napóleon hỏdítảsai megsẻrtették a nemzetek elrendeződését. Márpedig „a nemzeti egyediség eldarabolảsa mẻg mindig felkölté a nemzetiségre s nemzeti egységre való törekvés igyekezetét. Így van ez jelenleg is (...) Igenis, világerővel hat a nemzeti egység iránya, s amely nemzet parányiszerü indolentiában e világirányhoz nem simul, annak jövendője: elnyeletés, meg járom, szolgaság" "Szerinte a magyarországiak felismerték a nemzetiség „kifejtésének” szükségességét, ami az erdélyiekröl még nem mondható el.

A magyarság két nagy nemzet ${ }^{7}$ között veszélyes helyzetben van, amelynek kivédésére egyesülnie kell Erdélynek Magyarországgal. „Füzzön össze bennünket Erdéllyel a politicai egység kapcsolata, miként nemzeti rokonság egybefüz: és bátran nẻzhetünk az időnek elibe..." Háttérbe kell szorítani minden más szempontot. Az egységet a két ország kölcsönös akarata valósíthatja meg, amelynek egybe kell esnie az uralkodói érdekkel.

\footnotetext{
'Kossuth levele Wesselényihez. 1833. szeptember 1. Történelmi lapok I. évf. 1. sz. 1874. április 2. 2930

${ }^{6}$ Pesti Hirlap, 1848. április 14. 30. sz. A cikk kefelenyomatát l. Pajkossy vảlogatása, i.m. 32-34

${ }^{7}$ Kossuth az orosz és a német nemzetre céloz.
} 
Mindent végig kell gondolni: a függetlenség kérdésétől az úrbériségig. Kossuth úgy látta, hogy „az egyesüléssel veszteni semmiben, mindenben csak nyerni lehet." ${ }^{\circ 8}$

A lap következő számában Kossuth visszatért az unió ügyére. Elöször Erdély fuggetlenségét vizsgálta, amit egyes erdélyi politikusok féltettek: „Egy hóditónak karjait tárjuk-e mi felétek, mi magyarok vagy a szeretet s polgári egyenlőség testvéri karjait?" tette fel a szónoki kérdést, majd így válaszolt rá: „Fejedelmünk egy, alkotmányunk egy eredetü, s midőn két ily nemzet ${ }^{9}$ a fejedelem megegyeztével egyesül, és egyesül a nélkül, hogy a kisebb [ti. Erdély] jogaiból valamit veszítene, hogy a nagyobb ily veszteséget kívánna", és a közös alkotmány majd a közös elönyöknek biztosítéka lesz. A fuggetlenség elvesztéséröl ilyenformán nem lehet szó. ${ }^{10}$

Aztán Kossuth kifejtette, hogy az egyesülés a municipalitásra és nem a központiságra fog alapozni; és ha van Magyarországnak nádora, Horváthországnak pedig bánja, Erdélynek is lehet (továbbra is) kormányzója. Egyébként Erdély alkotmányáról számos kifogást fogalmaz meg Kossuth: az egykamarás országgyúlés is ilyen, amellett a királyi hivatalosak névsorát a gubernium terjeszti fel s ezek közill az uralkodó azokat hívja meg, akiket akar. Az országgyülésben a regalisták, a kormányszék a királyi tábla tagjai együtt vannak a törvényhatóságok és szabadhelyek követeivel. Az egyesülés után egy egészségesebb rendszer fog müködni, amely lehetövé teszi, hogy az ,a nemzeti lelkület”, amely Erdélyben az országgyúlésben annak minden hibája ellenére életre hívott olyan jeleneteket, melyeknél „a hazafinak örömében szíve repes”, ezután még csak növekednék. Kossuth azzal zárta a gondolatmenetét, hogy az ,erdélyi rokonaink” az egyesüléssel a törvényhozói rendszer jobbítása által ,ismét csak nyerhetnek"."

Kossuth egy év multán, 1842-ben Szózat a részek $s$ az Unió iránt Magyarhonból címủ írásában újra összegezte álláspontját ebben a kérdésben. Erre az adott okot, hogy a Részek visszacsatolását Magyarországhoz nem hajtották végre, holott erről 1836-ban országgyülési törvény született. Akkor Erdély országgyủlése ellenezte a Partium elszakítását Erdélytől, viszont azzal egyetértett volna a rendek többsége, hogy Erdélyt egészében csatolják vissza Magyarországhoz. ${ }^{12}$ Kossuth az erdélyi rendek akkori s néhány késỏbbi állásfoglalásából azt a következtetést vonta le, hogy az unió ügye előre haladt. „Mi egyesülni akarunk a testvérhonnal. Erdély mihozzảnk közelítést tőn. Vessünk vállat vállhoz, hogy az egyesülés igéje testté legyen, és a seb, melyet a Részek visszacsatolása okozott, az egyesüléssel orvosolva lesz, az egyesülésnek pedig annál kevesebb ellenzésre kellene találnia, mivel mint a magyar alkotmány védszárnyai alatt királyi városok, jászok és hajdúk municipiális jogait s kiváltságaik épségben tartása mellett megférnek, épp úgy a székely és

\footnotetext{
${ }^{8}$ „Mik vagyunk mi magyarok? Középre vetve két roppant nemzetiség közé, mellynek mindkettejéböl tömérdek elem zavarja sajátságunkat; úgy hogy, egyiknek, mint másiknak óceánjáról a habgyürüzet szivünkig elhat. Mi hát kikerülhetetlen hivatásunk ez állásponton? Kiállni az első rohanást, midön egykoron e két nagy elem összeütközik, éspedig kereken szólva, frigyesülni azon elemmel, mely mellett a világ színpadán a magyar elem nagyszerü önállásban békén megférhet, mellyhez királyunk trónérdeke barátságra hi, mellyhez a civilisatio s jog és szabadság közös eszméi vonzanak; frigyesülni pedig a másik ellen, melly már is vakondokkint turkálja ültetvényeinket, melly mellett önállás lehetetlen, mely elnyeléssel fenyegeti nemzetiségünket, mellynek elöcsapatja barbárság, és hagyománya járom és szolgaság. Füzzön össze bennünket Erdélylyel a politikai egység kapcsolata, miként nemzeti rokonság egybefüz: és bátran nézhetünk az időnek elibe. mellyben tán még egyszer hivatva leszünk védfalat képezni Európának." (Pesti Hirlap, 1841. április 14.)

${ }^{9}$ Ti. a magyarországi és az erdélyi magyar

${ }^{10}$ Pesti Hirlap 1841. április 15.31. sz.

11 Uo.

${ }^{12}$ Uo. 
szász székek s Erdélynek szabad helyei kiváltságaikkal, szabadságaikkal sértetlenül megférhetnek."13

Az erdélyi magyar (még alig kialakuló) ellenzék tulajdonképpen már az 1790-es országgyülésen az unió mellett nyilatkozott, s az erdélyi megyék és székek az 1790. július 18.-án keltezett magyar országgyüléshez küldött levelükben határozottan kifejezték az egyesülés iránti akaratukat. ${ }^{14}$ Bár ezután hosszú ideig nem került a politikai élet napirendjére az unió ügye, a reformkorban annál inkább terjedt az egyesülés eszméje. Elsősorban Wesselényi Miklós, majd id. Bethlen János, Kemény Dénes, Szász Károly az unió hívei, de amint Asztalos Miklós megállapitotta, e kérdésben „egységes politikai köztudat Erdélyben csak 1841-gyel, Kemény Zsigmond publicisztikai fellépéseivel kezd kialakulni" 15 Ezután az unió hívei mindkét országban szaporodtak. Magyarországon az országos ellenzéki konferencia 1847. március 15.-én a reformeszmék legteljesebb összefoglalásában az unióról a következö állásfoglalást tette közzé: „Célunk : a honpolgárok minden osztályának érdekeit nemzetiség és alkotmányosság alapján egyesiteni; melly végre a nemzetiség ügyének a más nyelvü népiségek érdekeinek óvatos kíméléseivel, s a vallás kérdésének a múlt országgyülési alapon bevégzésén kivül szükségesnek véljük: Erdélynek és Magyarországnak teljes és jogszerü egyesitését, hogy a két testvérhaza és testvér-nemzet egymásnak visszaadatván, ekképpen mind a vérségi kapcsolatnak, mind a törvény szentségének elégtétessék." 16

A fenti idézet azt bizonyitja, hogy Magyarországon vélemények halmazából politikai programmá vált az unió. És ez nem volt másként Erdélyben sem, ahol az ellenzéki mozgalom egyik meghatározó egyénisége, báró Kemény Dénes az 1845/1846-ban írt Honegység címü munkájában ${ }^{17}$ az egységet fő célként azért jelölte meg, mert „Erdély nem bír magára ország lenni”; Erdély nem is ország, hanem Ausztria egyik „legelnyomatottabb tartománya". Elmaradottságából csak a fejlettebb Magyarországgal való egyesülés által szabadulhat ki. Anyagi fellendülés csak az uniótól várható, ez által oldható meg az úrbériség kérdése is. ${ }^{18}$

Bár a magyar konzervativok körében mind Magyarorszảgon, mind Erdélyben nem kevés ellenzője volt Magyarország és Erdély egyesülésének, a közvélemény az unióbarát liberális reformellenzék álláspontját fogadta el, s igy 1848 előestéjén a magyarság többsége fel volt készülve a nemzeti s ,honegység " létrehozására.

Bécs azonban tartotta magát az 1790-ben kialakitott álláspontjảhoz, ahhoz ti., hogy Erdély és Magyarország különállását fenn kell tartani. Ehhez igazodott a szászok magatartása; a románság még kivárt.

\section{Kossuth és az unió 1848-ban}

Az unió és a polgárosodás kérdésében az 1848-as év ủj helyzetet teremtett: ha eladdig inkább elméleti politizálásról volt szó, az európai forradalom már az unió lehetőségét is felkínálta. Kossuth nem habozott kihasználni a februári párizsi forradalom

\footnotetext{
${ }^{13}$ Asztalos Miklós: Kossuth Lajos kora és az erdélyi kérdés. Budapest, 1928. 67-68.

${ }^{14}$ Sándorffy Kamill: Erdély reformkorának jogtörténete. Budapest, 2000. 503.

${ }^{15}$ Asztalos: i.m. 53

${ }^{16}$ Kossuth Lajos Összes Munkái (a továbbiakban KLÖM) I. Kossuth Lajos 1848-49-ben, Budapest, 1951. 121

${ }^{17}$ Kemény Dénes munkájának egy része 1861-ben jẹlènt mèg.

${ }^{18}$ Uo.
} 
által felszított politikai légkört, s az ellenzéki nemzeti mozgalom kívánságaiból új, cselekvési programot állított össze. Ebből nem hiányzott Erdély uniója.

A március 3.-i felirat jelzésértékú volt Erdély számára is.

Egy közismert ellenzéki, nemzeti elkötelezettségú politikusokból álló csoport „barátságos felszólítás”-sal fordult a magyarországi ellenzékhez, amelyben - annak alkotmányos küzdelmét méltányolva - kérték, hogy a magyar országgyúlés fogadjon el törvényt az unió gyors megvalósítása érdekében.

A felhívást aláíró 44 politikus között voltak a reformellenzék vezető egyéniségei: id. Bethlen János, ifj. Bethlen János, Teleki László, Teleki Domokos, Zeyk József. Az akció kezdeményezője $s$ az irat szerzője valószínủleg az ellenzék vezére, id. Bethlen János volt. ${ }^{19}$

Az erdélyiek a Kossuth által fogalmazott március 3.-i felirat szellemében állást foglaltak az alkotmányos monarchia mellett: ,Mi a két magyar hazában institutióinkat, a nemzetek egymáshozi viszonyait, azoknak fejlettségét megfontolva más igazgatási rendszert lehetségesnek nem tartunk mint alkotmányos monarchiát. ${ }^{20}$ Csakis az alkotmányosság ígér biztosítékot az ország fennmaradására s a vagyonbiztonságra. Az eddigi „,bürokratikus kormányzás" ${ }^{\prime 1}$ nem tartható fenn.

Ezt követően tér rá a felirat Erdély helyzetére. Az aláírók úgy látták, hogy az ,alkotmányos kifejlődhetésünk" s ,magyar nemzetiségünk fennmaradásának legerősebb biztosítéka [...] a két magyar hon eggyéolvadása". Az uniót „mi magunkra nézve életkérdésnek” tartjuk, s Magyarországra sem lehet „,csekély értékü” - írták az erdélyi politikusok. Aztán az indoklás következik: „Alkotmányos tekintetben két olyan hazának ugyanis, melynek népe eredetére, institucióinak nemcsak alapjaira, természetére, hanem kifejlödésére, szenvedéseire, örömeire nézve csaknem ugyanegy; melynek kívánata, reménye, nemzeti érzelme egynemú, ugyanazon igazgatás, ugyanazon alkotmányos rendszer alatti egyesítése, azon rendszer szilárdítására mennyi nyomatékkal bír, elég csak megemlíteni, mutogatni fölösleges volna."

Magyarország pillanatnyilag többet nyújthat Erdélynek, mint fordítva, de a kisebb segítséget sem lehet elvetni, mert annak veszélyes következményei lehetnek. Egyébként is: az erdélyi magyarság és a székelység ,kimeríthetetlen forrảsa lenne a magyar nemzetiségnek". Az egyesülésnek most kell megtörténnie, mert az európai események megindulása közepette „midőn az Alpok csúcsáról legördülő lavina”, hatását senki sem tudja megjósolni, ki tudhatja, hogy milyen nemzetek fognak egymással ősszefogni vagy egymásra támadni. Egyesülve Magyarország és Erdély jobban tud védekezni, mint különkülön. Az erdélyiek kérik a magyar rendeket, ne mulasszák el a kedvezỏ alkalmat az egyesülésre, ami biztos jövőt ígér a magyar nemzet számára.

Összegezve a fentieket: az aláirók az uniót életkérdésnek tartották, amely egyedül képes Erdély haladását, alkotmányos életét is biztosítani, ami az egész magyar nemzet érdeke. Egy ilyenformán egyesült Magyarország a trónnak, az uralkodónak is „legszilárdabb támasza" lenne. ${ }^{22}$

Az aláírók közül hiányoztak azok a neves ellenzéki politikusok, akik nem tartózkodtak Kolozsvárt, így Wesselényi Miklós, Kemény Dénes, Kemény Zsigmond, Pálffy János és mások. De a felirat tartalmazta az egész reformellenzék álláspontját. Ezt mind a korảbbi, mind a következỏ napokban-hetekben tanúsított magatartásuk bizonyította.

A pesti forradalom híre március 20.-án érkezett meg Kolozsvárra $s$ a magyar ellenzéki mozgalom vezérei, nagyrészt azok, akik a magyarországi reformellenzékhez

\footnotetext{
${ }^{19}$ A felirat tartalma és stílusjegyei alapján.

20 Magyar Országos Levéltár (a továbbiakban MOL). Az 1848-1849-i Minisztériumi Levéltảr. Belügyminisztérium. Általános iratok 38/1848.

${ }^{21} \mathrm{~A}$ bürokratikus rendszer az abszolút monarchia közigazgatásának volt az eszközc.

${ }^{22}$ MOL. Az 1848-1489-i Miniosztérium Levéltár. 13 m. Általános iratok 38/1848 
intézték a már elemzett feliratot, nyomban tanácskozni kezdtek a teendök felöl, s határozatot hoztak az unió és a polgári átalakítás felgyorsitásáért a már korábban elhatározott reformok megvalósitása által. Ezért az erdélyi országgyülés minél elöbbi összehivását sürgették, amelynek legföbb pontjaként az uniót jelölték meg. ${ }^{21}$ Március 21 .-én ${ }^{24}$ Kolozsvárt, nagy népgyülésen adták közre a határozatot, $s$ ez elindítójává vált Erdélyben az 1848-as forradalomnak.

A forradalom kitörésének hírét $\mathrm{s}$ a kolozsvári események summáját id. Bethlen János gyorsfutár által küldött rövid levélben tudatta Wesselényi Miklóssal Zsibón. A levél felszólitotta a testileg nagyon sérült, de még mindig a legnagyobb erdélyi politikust, hogy azonnal induljon Pestre és Pozsonyba Erdély, s föként az unió ügyét képviselni. Wesselényi nem habozott, a megbizatást nagy lelkesedéssel elfogadta: „Szent ügy az, melyben tisztelt soraitok hozzám intézvék, felszólitástokban nemzetem szavát gondolom érthetni. Ezt parancsnak veszem, megyek. Fájdalom, hogy e parancs nem érhetett eröm teljességében. Kevés az, mit nem csak akaratomhoz, hanem egykori erömhöz mérve is fogok tehetni. Azonban erömaradványim teljesen ez ügynek leendnek szánva. Isten velünk. Hív polgártársatok." 25

Wesselényi nagy készülödései között nem mulasztotta el Kossuthot értesiteni gondolatairól. „A lelkesültség örömviharában” ír s kér áldást Kossuthra s mindazokra, akik ki tudták használni a kedvezö fordulatot - ti. a bécsi forradalmat $-\mathrm{s}$ igy képesek voltak elérni mindazt, amiért rég küzdött az ellenzék. Mégsem lehet megfeledkezni arról, - írta hogy az abszolutizmus ,átkos tényezői”, a hierarchia, oligarchia s bürokrácia, a zsoldos katonaság mellett mindent el fog követni, hogy a kedvezöre fordult eseményeket rossz irányba fordítsák. Emellett a nép is megtanulhatja ,a szerencsétlen nemzeti dalból az esküszünk, hogy rabok többé nem leszünk"-et $s$ azt fogja rajta érteni, hogy sem a megyei, sem földesúri elöljáróinak többé ne engedelmeskedjék. Egy másik gondot a horvátok „hallgatása” okozott Wesselényinek, amelyet „vihar elötti csendnek” tekintett.

A veszélyérzet ellenére bízik a jövőben, $s$ ennek érdekében indul Pozsonyba az ,általános és teljes" unió ügyét szolgálni, mert a kolozsváriak felkérésében „nemzetem szavát vélte hallani". Nem mellékes kérdés, hogy Wesselényi teljesen egyetértett Kossuth koncepciójával a demokratikus átalakulások módját illetően: „Áldjon meg az ég azért is, hogy alkotmányunkat $\mathrm{s}$ képviseletét úgy mint parlamenti kormányt, megyei $\mathrm{s}$ törvényhatósági élet megtisztítandó s egyszersmind szilárditandó alapjára akarod fektetni."

Wesselényi nagy reményekkel indult el Pozsonyba. Közben Pesten népgyủlésen szónokolt s kitörö ünneplẻsben volt része.

Hogyan állt az unió ügye Pozsonyban, amikor Wesselényi megérkezett. $s$ milyen szerepe lehetett a VII., azaz az uniós törvénycikk megszületésében?

Tény - és ezt Wesselényi a Kis Károly jogügyi intézỏjéhez küldött levelében nem mellékesen vetette papirra -, hogy „Az unió dolgába már feljövetelem elött szerkesztettek az erdélyiek egy törvényjavaslatot, de amelyet én nem szerettem. Mást szerkesztettünk, s az mind a két táblánál átment.".27

Lássuk, milyen törvényjavaslatot vetettek el Wesselényiék, és milyen más javaslatot szerkesztettek.

Kemény Dénesnek egy 1848. március 22.-én kelt s Kossuthoz címzett levelében utalás történik egy olyan javaslatra, amely „formulázva Kendnél van”. A levẻl arra kérte

${ }^{23}$ Egyed Ákos : Erdély 1848-1849/. Csikszereda, 1998. 56-62.

${ }^{24}$ E napot nevezték „Erdély március tizenötödikéjének”.

${ }^{25}$ Az Erdélyi Múzeum-Egyesület (EME) Levéltára a Kolozsvári Állami Levéltárban (KvÁLvt). Wesselényi Miklós levélmásolatai. 34. kötet. 291.

${ }^{26}$ Uo. I. még Kardos 11. Budapest, 1905. 197. I.

${ }^{27}$ EME Lvt a KVÁLvt-ban. Wesselényi Miklós levélmásolatai. 34. kötet 
Kossuthot, hasson oda, hogy Eṛdély utolsó országgyülését Pesten tartsák. Ezt Kossuth április másodikán „Magyarország és Erdély törvényhozási egyesitéséröl” címmel terjesztette elö. De a rendek kerületi ülésén április 5.-ére kitüzött vitát maga Kossuth állitotta le azzal az indokkal, hogy a Partiumból érkező követek e kérdésben „több felvilágositást adhatnak”. Urbán Aladár okkal mutat rá arra, hogy a március 15.-e elötti szellemben fogant elöbb említett törvényjavaslatot a Pozsonyba érkezett Wesselényi Miklós és Beöthy Ödön amiatt kifogásolták, hogy e törvényjavaslat csak a két országgyülésnek az egyesitését írta volna elö. ${ }^{28}$

Wesselényièk tehát elvetették ezt a részleges egyesülési tervet, $s$ kidolgozták a teljes egyesülésröl szóló törvényjavaslatot. Az erdélyi magyar nemzeti mozgalom korábbi vezéréhez, id. Bethlen Jánoshoz Pozsonyból, április 10.-én küldött levelében Wesselényi számol be a történtekröl. (Figyeljük meg, hogy Wesselényi mindig többes számot használ, amikor a törvényjavaslat megalkotásáról beszél, pedig tudjuk, hogy a felsőházban ő vitte keresztül azt a törvényjavaslatot, amely nem tartalmazta Erdély elözetes beleegyezésének klauzáját ahhoz, hogy képviselői megjelenhessenek a magyarországi népképviseleti országgyúlésen.) A Bethlen Jánosnak címzett fent említett levélben beszámol arról is, hogy Bécsben az uniós törvényjavaslat „leglényegesebb része megtört”, mert beiktatták azt a feltételt, hogy a közelebbi „magyarhoni közgyülésbeni részvét” az erdélyi országgyülés beleegyezésétöl függiön. Wesselényi szerint ez a módositás maga után vonja azt, hogy az ellenzök „Most már természetesen kézzel-lábbal azon lesznek, hogy a közelebbi erdélyi országgyülést unió ellenzésére bírják.” Ezért a teendőket is kijelöli : az unió ügyét „divat és közvélemény tárgyává" kell tenni, sőt azt hiszi, hogy jó lesz, ha több törvényhatóság elöre elhatározza: bármint dönt az erdélyi országgyülés, követeket fog küldeni Pestre az országgyülésbe. Petíciókampány meginditását is javasolja a magyar kormányhoz $\mathrm{s}$ folyamodás küldését őfelségéhez, mert úgy látja, hogy ,az unió életkérdéssé vált Erdélyre és a magyar honra is." 29

A fentiekben jelzettekkel azonban még nem ért véget Wesselényi pozsonyi küldetése. Miután Kossuth meghallgatta Beöthy Ödönt és Wesselényit, javaslatot terjesztett elö az 1836:21 tc. végrehajtásáról, vagyis a Partium reincorporátiójáról. Wesselényit a visszacsatolás királyi biztosává nevezték ki (Zarảndban Beöthy Ödön kapott hasonló megbizatást).

Kossuth azért tartotta életkérdésnek az uniót, mert az erdélyi magyarság a vármegyékben már kisebbségi helyzetbe került, száma fogyatkozott. Abban is teljesen azonos módon gondolkozott Wesselényivel, hogy az unió csak akkor lehet végleges, ha azt Erdély más népei is elfogadják. Kossuth és a magyar nemzeti mozgalom vezetôi a nemzetiségi kérdést az általános szabadságjogok kiterjesztése által vélték rendezhetőnek. Ezáltal nyerhetỏ meg a román nép is az egyesủlésnek Magyarországgal, ahol már március óta szabad a jobbágy. Ezért siettek Kossuthék összekötni az uniót a jobbágyfelszabadítás kiterjesztésével Erdélyre. Ezt törvényes úton az utolsó országgyülés végezte el.

$\mathrm{Az}$ 1848. május 29.-én Kolozsvárt összeült erdélyi országgyülés május 30.-án Kolozsvárt az első cikkelyében kodifikálta az uniót. ${ }^{30}$ Ezt a király 1848 . június 10 .-én ellátta kézjegyével, s ezzel az egyesülés jogilag létrejött. Az uniótörvény az egyesüléssel egyszerre nyilvánitotta ki kellő nyomatékkal a polgári nemzet legalapvetőbb tételét: „Valamint a testvér Magyarhonban minden lakosok jogegyenlösége kimondva és életbe léptetve van, ugyanaz, ugyanazon módon itt is, e hazának minden lakosaira nézve nemzet-, nyelv- és

\footnotetext{
${ }^{28}$ Urbán Aladár: Batthyány Lajos miniszterelnöksége. Budāeest. 1986. 222-223

${ }^{29}$ EME Lvt a KvÄLvt-ban. Wesselényi Miklós levelezése. 34. kötet

${ }^{30}$ Egyed Ảkos: Erdély országgyủlése. i.m. 74-95. 
valláskülönbség nélkül örök és változhatlan elvül elismertetik, és az evvel ellenkezỏ eddigi törvények ezennel eltöröltetetteknek. nyilváníttatnak."

Vagyis: Erdély minden lakója polgárilag jogegyenlö, ami a rendiség, a rendi nemzetek jogi megszüntetését jelentette. A sok évszázados erdélyi rendiség Kolozsvárt 1848. május 30.án végképp átadatott a történelemnek.

A kolozsvári történelmi esemény hírét mások mellett a neves közíró, késöbbi kivảló történetíró Jakab Elek vitte a magyar kormányhoz Pestre. Jakab Elek beszámolt a fogadtatásáról is. A kormány tagjai, Széchenyi István is sietett kijelenteni: örül az eseménynek.

Kossuth meleg együttérzéssel fogadta Jakab Eleket, hiszen unióspolitikảjának megvalósulását látta ebben. „Három százados szétdaraboltatása utản ismét egy hazánk [...]. Erdély egyesülése nagy erögyarapodảs Magyarországra nézve, de önökre $s$ a [erdélyi] vármegyei magyarságra nézve - a kétszer nagyobb számủ olảhság miatt éppen életkérdés." ${ }^{11}$

Több mint érdekes: Kossuth ugyanazon kifejezést használta, melyet Wesselényi : „életkérdés”, ti. az erdélyi magyarságra nézve. Hasonló módon gondolkodtak arról is, hogy az uniót a jobbágyfelszabadulással össze kell kötni. „Nincs semmi mit inkább kellene tele torokkal kiáltani, mint azt, hogy azért kell unió, mert az oláh és magyar paraszt egyszerre szabaddá lesznek s az oláh és magyar paraszt egyszerre mindazon jogokban részesülend, melyek eddig csak nemesekéi voltak; ezek pedig az ország terheit az eddigi parasztokkal együtt hordozandják, továbbá, hogy egyik vallásbelinek $s$ egyik nemzetfiảnak szintannyi joga leend, mint a másikból valónak." 32

Az országgyülésben Wesselényi terjesztette elö a jobbágyfelszabaditó törvény tervezetét: „Szent ügy az melly mellett szavamat emelem” - kezdte élete egyik legszebb beszédét. Azokról beszél - mondotta - , akik eddig a terheket hordozták, akit ez az ügy nem hat át részvéttel, annak a szájában nem valóság, csak ,pengő üres hang a kor hảrom dicső jelszava: szabadság, egyenlőség, testvériség (...). Legyenek az eddigi jobbágyok és zsellérek többé nem parasztok, misera plebs, hanem szabad polgárok." ${ }^{33}$ Azt kell tenni Erdélyben is, ami a testvér Magyarhonban már hónapok elött megvalósult: szabaddá kell tenni a jobbágynépet. Valóban, 1848. június 6.án megfogalmazták Erdély országgyülésében a kor egyik legjobb úrbéri jobbágy-felszabaditó törvényét: az eddigi jobbágyok szabad polgárokká váltak s földtulajdonosok lettek.

A jobbágyfelszabaditásnak egész Erdély nyertese volt: megszabadult a rendi-feudális világ haladást gátló béklyóitól: az erdélyi jobbágytörvény több mint másfél évtizeddel korábban tette szabaddá az embert és a földet, mint Oroszországban vagy Romániảban. És sokkal elönyösebb feltételek mellett: Magyarországon és Erdélyben az állam vállalta magára a földesurak kárpótlását az elveszett jobbágyi szolgálatokért, holott példảul az 1864-es román fơldtörvény szerint a parasztságnak kellett önmagát megváltania.

Ezzel mind az unió, mind a jobbágyfelszabadulás megtörtént, mindkettỏ alkotmảnyos úton. Kossuth - akárcsak Wesselényi - azt remélte, hogy a törvények gyakorlati megvalósitása is békés körülmények között fog megtörtẻnni. Ennek érdekében dolgozott Pesten az első magyar népképviseleti országgyưlés, amelyen 73 erdélyi követ is jelen volt.

\footnotetext{
${ }^{31}$ Jakab Elek: i.m. 179.

${ }^{32}$ EME Lvt a KvÁLvt-ban 35. köt.

${ }^{33}$ MOL. F. 135. Cista Diplomatica Diaetalia, 78. köt.
} 


\section{Az Erdélyre vonatkozó törvények és törvényjavaslatok a magyar népképviseleti országgyülésben. Kossuth szerepe}

Az erdélyi országgyủlés 1848. május 30.-án, az uniótörvény megszavazásakor létrehozta az unióbizottságot azzal a céllal, hogy Erdély érdekeit képviselje s javaslatokat terjesszen a kormány és a magyar országgyülés elé a megfelelö törvẻnyhozó munka elösegítésére. Az unióbizottság a népképviseleti országgyülés keretében fejtette ki tevékenységét.

Mivel az országgyủlés teljes ülése és az unióbizottság is tárgyalta Erdély ügyeit, a következőkben mindkét fórum munkáját nyomon kell követnünk.

Az első kérdés, amellyel a pesti országgyủlésnek szembe kellett néznie, a székelyföldi jobbágyfelszabadulás ügye volt. Erre az adott alkalmat, hogy Perényi Zsigmond Erdélyben tartózkodó országgyülési biztos jelentette a magyar kormánynak: a készülö erdélyi jobbágytörvény a Székelyföldön nem lesz alkalmazható, mert a székelység Csíkban és Háromszéken túlnépesedett, a föld viszont kevés, tehát a jobbágyságnak nem fog jutni belöle. Az erdélyi jobbágytörvény a székelyföldi jobbágyoknak csak mintegy 10 százalékát szabadította fel megfelelö jobbágytelekkel, mert a „székelyörökséget" allodiatúrának nyilvánította. ${ }^{34}$

A székely jobbágyügy a magyar országgyülésben vitát váltott ki, amelyben Kossuth Perényi javaslatait karolta fel, vagyis azt, hogy a székely szegénységet telepítsék a Délvidéken levő kincstári pusztákra. Ezzel egyidőben került volna sor a moldvai csángók hazatelepítésére is.

Jủnius 19.-én átiratot küldött Trangous Lajos bányászati osztályigazgatóhoz, amelyben arról érdeklödött, hogy lehetne-e elegendő helyet találni a Bánságban és Bácskában az ott letelepedni akaró székelyek és csángók számảra. „A határszélek biztosítása egyrészröl - másrészről a nemzetiség érdeke igen fontossá teszi, hogy a túlnépesedett székely vidékek, nem különben a moldvai csángó magyarok Magyarországba, s különösen Bánátba telepítessenek - olly tömegekben, mellyek szükség esetén az ellenségnek ellenállni, minden esetre pedig nemzetiségïket fenntartani képesek legyenek." az áttelepítést. Mivel a válasz kedvezö volt. Kossuth már július 26.-án törvényjavaslatot nyújtott be. Ebben a kincstári javakat jelölte meg a telepítések lehetséges helyeként, kérve a képviselöházat, hogy ,a magyar vidékek közt a leginkább túlnépesedett székelységre terjessze ki figyelmét". A törvényjavaslat négy pontból állt, éspedig: 1. az ország pénzügyminisztere felhatalmazást kap, hogy a Bács, Torontál és Krassó megyékbeli kincstári javakra bármi nagyobbszerü magyar telepítéseket hajthasson végre; 2 . a pénzügyminiszter a székelyekre különös figyelmet fordỉt, s azok, akik a harcmezőn kitủntek. „mások felett” kedvezőbb feltételek mellett telepedhetnek le; 3. egy-egy letelepedőnek nyújtandó birtok terjedelme nem lehet kisebb, mint amennyi egy család élelmét $\mathrm{s}$ önellátását biztosítja. Az egy helyen letelepedö csoportnak akkorának kell lennie, amely a csoport folytonosságát biztosítja és 4 . a telepesek bizonyos, meghatározott kedvezményekben részesülnek, hogy birtokaikat megtarthassák.

A képviselöház augusztus elsején némi módosítással törvényeröre emelte Kossuth előterjesztését. A vitában felszólalt Berzenczey László, s határozottan támogatta Kossuth előterjesztését, amelyet - akárcsak az elöterjesztő - a „honvẻdelem eszközẻnek” tartott.

34 A jobbágyviszonyok megszüntetése Erdélyben. Jobbágyfelszabadulás 1848. szerk. Varga János.

Budapest, 1998. 44-53.

${ }^{35}$ KLÖM. XII. 295. 
Látva hozzáállását, Kossuth augusztus 2.-án Berzenczey Lászlót kinevezte miniszteri biztossá a telepítés lebonyolítására. Ezzel megkezdődött Kossuth és Berzenczey László marosszéki követe konkrét, 1848 novemberéig tartó szoros együttmüködése.

Berzenczey hozzá is kezdett az elökészületekhez, de végül is az áttelepítésböl semmi sem lett, részben a Délvidéken bekövetkezett háborús állapotok miatt, föként pedig amiatt, hogy a székelység nem volt hajlandó a tömeges áttelepedésre. Emiatt bukott meg egyébként Bem 1849-es áttelepítési terve is. Bem Beszterce vidékre szerette volna a szegényrendủ székelyeket telepiteni. Nem jelentéktelen kérdés, hogy Kossuth ezt a tervet ellenezte, mert úgy vélte, hogy az sértené az ottani románság érdekeit. Ez is alátámasztja Deák István ama megállapitását, hogy Kossuth elvetett minden kollektív büntetési formát. ${ }^{36}$

A telepitési terv meghiúsulása egyben a székely jobbágykérdés megoldásának elodázását is jelentette, ami nem kis társadalmi feszültséget okozott a Székelyföldön, kitünő talajt szolgáltatva az unió-ellenes és magyar nemesség-ellenes propagandának.

Mialatt a teljes ülésben a szegényrendü, voltaképpen az erdélyi jobbágytörvényböl kimaradó székely jobbágyság-zsellérség ügyéről folyt a tanácskozás, az unióbizottság az erdélyi országgyülés úrbéri törvényét tárgyalta meg. A július 23 .-i ülést az a kérdés foglalkoztatta, hogy mi tekinthetỏ úrbéri, illetve allodiális természetủ földnek, a bizottság az erdélyi törvény alapelvét erösítette meg azzal, hogy kimondta: tekintsenek úrbérinek minden olyan földet, amely a törvény kihirdetésekor jobbágykézen volt. $\mathrm{S}$ ha ebben a földesúr meg nem nyugodnék, maga tartozzon bizonyitani az ellenkezỏjét. A bizottság az irtásföldek tekintetében olyan megoldást javasolt, hogy a 32 évnél régebben tett irtások maradjanak a jobbágy tulajdonban, az újabbak, amennyiben a földesúr tiltakozása ellenére vitték végbe. legyenek a földesúré. ${ }^{37} \mathrm{~A}$ vitás kérdések eldöntésére a minisztérium bizottságokat nevezzen $\mathrm{ki}, \mathrm{s}$ a tagok megválasztásánál legyen tekintettel a nemzetiségekre, a szász városi törvényhatóságokra és a városi polgárokra. ${ }^{38}$

Kossuth az unióbizottsággal - amint már említettük - kapcsolatot tartott fenn, igy valószinüleg tudomása volt az úrbéri ügyekben hozott ajánlásokról is. Kossuth a jobbágyfelszabadulás elkötelezett híveként elvileg egyetértett minden elfogadhatónak, pláné jónak itélt javaslattal, de közbelépett, ha ennek ellenkezöjét tapasztalta. Például 1848 nyarán, amikor román forrásokból arról értesült, hogy a kincstári birtokokon még „dézsmát" szednek, nyomban utasitotta Vay Miklós királyi biztost, hogy intézkedjék a visszásság azonnali orvoslásáról, mert „a dézsmaadást sem igazságosnak, sem méltányosnak, sem politikai tekintetben hasznosnak nem itélhetem.." ${ }^{39}$ Kossuth ezt megelözően is foglalkozott az erdélyi dézsma ügyével, $s$ már augusztus elsején bejelentette a képviselőházban, hogy a kincstári dézsmákról megtette a szükséges intézkedést, megszüntette, de arról, hogy a szász papok is ugyanezt tették - nincsen tudomása. ${ }^{40}$

Kossuth a jobbágyfelszabaditás vivmányáról még a forradalom veresége esetére is biztositani kívánta a parasztságot, de nem akarta tönkretenni a nemességet sem: "Én biztositani akarom a nép szabadságát, $s$ egyszersmind azt is, hogy a nemesség a maga

\footnotetext{
${ }^{36}$ Deák István: Kossuth Lajos és a magyarok 1848-1849-ben, Budapest, 1983. 287.

${ }^{37}$ Márki Sándor: i.m. 324-325.

${ }^{38}$ Uo.

${ }^{39}$ KLÖM. XII. 462-463. L. még Kossuth Lajos izenetei. Összeállitotta Szabad György, Budapest. 1994.114

${ }^{40}$ KLÖM. XII. $661-662$.
} 
kármentesítését kapja meg." ${ }^{41} \mathrm{Ez}$ a politika Kossuth koncepciójának demokratizmusát bizonyítja, valamint azt, hogy számára az érdekegyesítés reformkori jelszava a forradalom idején is időszerü feladat maradt.

$\mathrm{Az}$ unióbizottság rendre megtárgyalta az unióval kapcsolatos kérdéseket és törvényjavaslatokat dolgozott $\mathrm{ki}$ a teljes egység megvalósítása érdekében. Ezeket a javaslatokat aztán a kormány, illetve az országgyülés elé kell terjeszteni, de idöhiány miatt ezt az utat nem minden javaslat tehette meg. A legfontosabbak elöterjesztését maga Kossuth szorgalmazta. Érdemesnek tartjuk idézni a szeptember 15.-i ülésen elhangzott szavait: „Bátorkodom az érdemes követ urakat, kik Erdélynek viszonyaival közelebbröl ismeretesek, szivesen felkérni, hogy a roppant mostani teendök közt, az ollyan dolgokra, mellyek várhatnak, vagy kormányilag is elintézhetők, az ollyanokra most az idöt nem pazarolva, a legszükségesebb teendök iránt, mellyeket Erdélynek tenni kell, szíveskedjenek velünk nyomban közölni a magok törvényjavaslatát, miszerint Erdély tekintetében is a törvényhozás megmutathassa, hogy midön Erdély Magyarországgal egyesült, nyert jogban, szabadságban, jóllétben, terhei pedig, kevesbedtek." Felkérte a bizottságot és a követeket, hogy elöterjesztéseiket a minisztériumok tegyék meg. ${ }^{42} \mathrm{Mi}$ több: a törvényalkotás elömozdítására Kossuth Pálffy Jánossal együtt dolgozott ki törvényjavaslatokat Erdélyre. Ezek közé tartozott a közigazgatás, a székelyek és a határörvidéki katonaság sérelmeiröl s az igazságszolgáltatásról szóló törvény. Azonban ezeket megelözően Nyáry Pál előterjesztette A jobbágyviszony végképi megszüntetéséról címü törvényjavaslatát. ${ }^{43}$ Kossuth a vitában két alaptételt fogalmazott meg a javaslattal kapcsolatban: olyan törvényt hozzon az országgyülés, mely végképp megszünteti a jobbágyviszonyokat úgy, hogy emiatt „a volt nemesség vagyonilag tönkre ne menjen", $s$ legyen kedve a hazát védeni. ${ }^{44}$

Amint már emlitettük, Kossuth rendeletileg tiltotta meg, hogy az erdélyi kincstári birtokokon dézsmát szedjenek a volt jobbágyoktól.

Kossuth a szeptember 15.-i ülésben egyenes felszólitást intézett az erdélyi követekhez: „tessék előadni nézeteiket, hiszen mindnyăjunkat csak az vezet, hogy Erdélyben minél több rokonszenvet költsünk, mert mi testvérileg akarjuk ölelni, kiket törvényileg magunkhoz kapcsolunk." ${ }^{45}$

Elöször közigazgatási törvẻnyt terjesztettek be, amely az erdélyi kirảlyi kormányszék és a kincstár megszüntetését mondotta ki, valamint azt, hogy Erdély katonaủgyét a magyar hadügyminiszter fogja ezután intézni. Az országgyülés aztán az igazságszolgáltatás, majd a következő ülésben a székely határörrendszer feloszlatásának kẻrdéseit vitatta meg. (A székelykérdést külön fejezetben tárgyaljuk.)

Bármennyire fontosak voltak azonban a fenti törvények, gyakorlati alkalmazásukra 1848 öszén, az Erdélyben kitört polgárháború miatt nem kerülhetett sor. Višzont 1849-ben,

${ }^{41}$ „Én ... mert akarom, hogy a nemesség kármentesítve legyen, s ezen kármentesỉtés következtében biztosítva legyen a népnek is szabadsága, még a reactio esetében is, azt akarom, ha minden elveszne is Magyarországon, legalább az ne vesszen el, hogy a nẻp nyakát a robot ne nyomja; ezt akarom. mondom, elérni, mert azon reactio, mellyben sok aristocraticus nevek dolgoznak, ha gyözne, nem az következése, hogy a nemes ember, a birtokos elveszítse egészen ingyen az úrbériségeket, de nem is az volna következése, hogy a status adjon neki kárpótlást, mert az absolutismus, a melly alkuba bocsátkozott az olygarchiának camarillaris részével, ha gyözne, az volna következése, hogy marad ugyan szabadság, de azon ember egészen maga fizesse a megváltás terhét. Ezek valószínü eventualitások, ezeknek akarom útját vágni. Én biztosítani akarom a nép szabadságát, s egyszersmind azt is, hogy a nemesség a maga kármentesítését kapja meg." (KLÖM. XII. 991.)

${ }^{42}$ Kossuth Hírlapja, 1848. szeptember 16. 67. sz.

4s Az 1848. évi július hó 2,-ára ôsszehivott országgyủlés iromámyjegyzéke. Magyar Országgyủlési Könyvtár 70029 sz. 72-73. (Ezután Országgyülési irományjegyzék)

${ }^{44}$ Kossuth Hirlapja, 1848. szeptember 21.

${ }^{45}$ Uo. 
miután Bem tábornok Erdélyt felszabadította az ellenséges katonai megszállás alól, az 1848as törvényeket Kossuth igyekezett életbe léptetni.

Természetesen az unióbizottság napirendjén szerepeltek az utolsó erdélyi rendi országgyülésen elfogadott törvények, amelyeket megfelelö kiegészitésekkel ellátva a magyar törvények közé iktattak. Ezek az uniótörvény, a választói törvény, valamint az úriszolgálat a dézsma eltörléséröl, a nemesi kárpótlásról, a közös teherviselésröl, a sajtóról hozott törvénycikkek.

Kossuth tehát joggal jelentette ki, hogy Erdély uniója a jogalkotásban megtörtént. Csakhogy a „szeptemberi fordulat” Erdélyben annál is súlyosabb következményekkel járt, mint Magyarországon, mert a hivatásos haderö, $\mathrm{s}$ a román határörezredek egyszerre lázadtak fel a magyar kormányzat ellen, s ezzel egyidöben szervezödött meg a román és a szász népfelkelés Puchner tábornok, erdélyi föhadparancsnok irányitásával.

Ilyen körülmények között többszörösen sürgös teendö volt a nemzetiségi kérdés, föként az erdélyi románkérdés törvényi rendezése. Erre vállalkozott 1848 öszén a magyar népképviseleti országgyülés Kossuth Lajos hathatós biztatására s tényleges támogatásával.

\section{Kossuth Lajos és a román kérdés 1848-ban}

Az 1848-as törvényhozást és Kossuth Lajost gyakran érte az a vád, hogy túl késön kezdett foglalkozni a nemzetiségi kérdéssel, és amikor végre 1849. július 28-án elfogadták a nemzetiségi törvényt, az már semmit sem használhatott a magyarok és a nemzetiségek között elmérgesedett viszony rendezésében. Ez a felfogás él napjainkban is a román, szlovák, horvát és szerb történetírásokban, amelyek nem csak a késedelmeskedés miatt marasztalják el Kossuth Lajost, hanem felelössé is teszik a viszonyokban 1848-1849-ben bekövetkezett konfliktusokért, fegyveres konfrontációkért. Nem csoda, hogy a román, szlovák, szerb (talản kevésbé a horvát) közvélemény Kossuthban ma is ellenséget lát.

Természetesen nem nehéz a dolga annak a kutatónak, aki néhảny, rendszerint a szövegösszefüggéseiböl kiragadott $s$ a pillanatnyi körülmẻnyeket figyelmen kívül hagyỏ elrettentő Kossuth-idézettel próbálja bizonyítani állítása helyességét. Mert Kossuthnak tényleg voltak olykor kemény, megrovó, fenyegetőnek felfogható szavai a nemzetiségi mozgalmak vezetöi felé, amikor szerinte félrevezették a tömegeket, $\mathrm{s}$ a magyar forradalom által kivívott, a nemzetiségekre is kiterjesztett társadalmi jogokat és szabadságjogokat a császár kegyének tulajdonították. Vagy amikor az orszảg területi integritását veszélyeztető követelésekkel léptek föl, sőt magyarellenes fegyveres felkelẻseket szerveztek, atrocitásokat követtek el. A példák közismertek; ezek felsorakoztatásától eltekinthetünk. Szóljunk inkább arról, hogy egy reálisabb, valósághübb Kossuth-kép kialakítảsát $s$ elterjesztését neheziti például az a sajnálatos tény, hogy több mint másfél századdal a forradalom és szabadságharc után még nem rendelkezünk egy korszerü Kossuth-életrajzzal. Nem hozott ảttörést ezen a téren a 2002-es Kossuth-év sem. De tévednénk, ha nem vennénk észre a számos tanulmányban, kisebb elemző, illetve forrásközlő kötetben mutatkozó eredményeket. Ezek számbavételére persze itt nincsen terünk; nem is ez a szándékunk. $S$ ha két, egyébként nem nagy terjedelmü önálló kiadványra mégis hivatkozunk, tesszük azẻrt, hogy illusztrálhassuk fenti állitásunkat.

Az egyik Szabad György Kossuth irányadása cỉmủ könyve, amelyben végigkíséri Kossuth következetes törekvését, hogy a magyar államberendezkedés megújitásában polgárosítandó önkormányzatok mellözetlen szerephez jussanak. A neves szerzö meggyözöen cáfolja azt a sokat hangoztatott tévhitet, hogy Kossuth hajlandó lett volna 
diktátor lenni. ${ }^{46}$ A másik szerző, akit megemlítünk, Erdődy Gábor, aki számos magyar kutatóval ellentétben, Kossuth külpolitikájának realitását bizonyítva hangsúlyozza: mint a magyar polgári átalakulásért folytatott küzdelem vezéralakja, Kossuth 1848-ban sikeresen használta ki az európai forradalmi hullámot, s Habsburg-uralkodóval, magyar királlyal szentesítette a nemzeti önrendelkezést megalapozó törvényeket; Kossuth reálpolitikus mivoltát jellemezte az is, hogy a románokkal megkötötte a megbékélési szerzödést, ezzel is siettetve a nemzetiségi törvény megszületését. ${ }^{47}$

Kossuth Erdély-politikáját kutatva, e sorok íróját elsösorban az érdekelte, hogy milyen elözményei voltak a magyar nemzetiségi törvény megszületésének, pontosabban hogy Erdély uniójának milyen szerepe lehetett a nemzetiségi törvény elökészitésében. Vajon tényleg annyira késỏn, vagyis csak a szabadságharc utolsó heteiben döbbent rá Kossuth s a magyar törvényhozás a nemzeti kérdés rendezésének korparancsára? Arra gondolva, hogy ezen a téren minden szónak, elöre tett jogkiterjesztỏ lépésnek ugyancsak nagy jelentősége lehetett, lássuk kissé részletesebben a magyar népképviseleti országgyülésben a nemzetiségi kérdés körül zajló vita néhány napjának történetét.

Induljunk ki tehát abból: Kossuth Erdély-politikảja arra irányult, hogy az uniót a polgárosítással kösse össze. Vagyis, hogy azokat a politikai $\mathrm{s}$ társadalmi vívmányokat, amelyeket a magyar forradalom békés eszközökkel elért, Erdélyre is kiterjesszék. Ennek során különös fontosságot tulajdonított a románok megnyerésére a folyamatos jogkiterjesztés által. Nagyon bízott abban, hogy a jobbágyfelszabadítảs, amely a románság 9/10-ének szabadságot hozott, a törvény elötti egyenlösẻg, a közös teherviselés és más polgárosító törvények kellö méltánylást, elismerẻst vảltanak ki a románokban, $\mathrm{s}$ hajlandók lesznek együttmúködni a magyar vezetéssel a honpolgári együttélés lehetőségeinek kimunkálásában.

Az elsỏ magyar népképviseleti országgyülés 1848. július 5.-én nyílt meg Pesten, ahová az erdélyi követek, valamivel késöbb, részletekben érkeztek meg. A kétkamarás országgyülés képviselőházának egyik alelnökévẻ az udvarhelyszéki Pálffy Jảnost, az unió elszánt hívét választották meg, aki az országgyủlésben Kossuth tảmogatója, majd békepárti ellenfele s a Magyarországi és erdélyi urak címü elhíresült $\mathrm{s}$ folyamatosan idézett naplójában kegyetlen $\mathrm{s}$ a legtöbb esetben igazságtalan, vagy féligazságokat hangoztató bírálója lett. Mindezt azért láttuk szükségesnek elmondani, mert az egyébkẻnt nagytehetsẻgủ emlékíró Kossuth-képe ma is ható, erösen szubjektív törtẻneti forrás, másrészt - amint látni fogjuk - együtt nyújtottak be törvényjavaslatot Erdély közigazgatásával kapcsolatban.

Kossuth Erdélyt - akárcsak Széchenyi és Deák Ferenc - föként bảró Wesselẻnyi Miklós írásaiból s a vele való kapcsolatok által ismerte. Nézeteik az unió s a nemzetiségi kérdésben nem sokban különböztek egymástól. Nem véletlen, hogy a magyar országgyülés felsőházának augusztus 25.-i ülésében Wesselényi Miklós nyújtott be indítványt azzal a céllal, hogy szólítsák fel a képviselöházat: hozzon határozatot, melyben kifejezi ,a honban lakó népiségek, különösen az oláhok iránti rokonszenvét, továbbá, hogy azok jogait szintén örzi, mint a maga érdekeit. Végre pedig szólítsa fel a ministeriumot „ez ügyben törvẻnyjavaslat hozatalára."

Jegyezzük meg à dátumot: 1848. augusztus 25.-én az országgyủlés felsöháza elfogadta Wesselényi javaslatát egy nemzetiségi törvény szükségességérơl. Wesselényi beadványa azt is kérte, hogy az erdélyi országgyülésben megválasztott, de július 5.-e utản a pesti országgyülésben tevékenykedő unióbizottságnak a két orszảg egyesülését szabảlyozó, készülöben levő javaslata, „készítsen és terjesszen elö olly törvényjavaslatot, melly az

${ }^{46}$ Szabad György: Kossuth irányadása. Budapest, 2002. 62-83.

47 Erdödy Gábor: Kossuth Lajos. A demokratikus polgári átalakulásért és a nemzeti önrendelkezés kivívásáért folytatott küzdelem vezéralakja, Budapest, 2002. 38-39: 50-66. 
erdélyi román ajkúak nyugalmának eszközlésére sikeres legyen." ${ }^{48}$ Wesselényi javaslata öt paragrafusban kívánta biztosítani a görög egyesült és nem egyesült vallásoknak a többi keresztény vallásokkal való egyenlő jogait, egyházaik önkormányzatát „a felelős ministeriumnak alkotmányos felügyelete alatt", valamint az elemi fokú oktatás anyanyelvủségét, a román közösségek jegyzőkönyv vitelének román és magyar nyelvü szerkesztését, valamint azt, hogy „a román nyelven írt kérvények, kötlevelek s más magány oklevelek mindenhol elfogadandók". Egyáltalán nem érdektelen az itt következő kíséröszöveg, amellyel Wesselényi a saját törvényjavaslatát elöterjesztette: A felsőház kifejezi, s az alsóházat is barátságosan felszólitja annak kifejezésére: „miszerint a házak s az összes törvényhozás, a honunkban lakó kủlönbözỏ fajuak és ajkuak, s azok közt az oláhok, vagyis románok iránt rokon $s$ testvéries érzettel viseltetik; velök a nemzet minden megosztható jogait szívesen megosztja; az alkotmányos közös szabadság s jog és kötelezettségbeli egyenlöség által, sorsukat úgy mint érdekeiket a saját magáéihoz kívánja csatolni, s azokat az alkotmány oltalma alatt állónak vallja."49

Úgy véljük, Wesselényi törvényjavaslatát $\mathrm{mi}$ is elfogadhatjuk a majdani 1849.-i nemzetiségi törvény szerény kiindulópontjának. A csírák közé sorolandók azok a viták is, amelyek az országgyülés alsóházában az állampolgárok egyenlöségéröl korábban hozott törvények gyakorlati alkalmazása kérdésében folytak.

Az augusztus 24. és 26.-i vitảt két dolog váltotta ki. Az egyik az, hogy Kossuth tudomására jutottak azok a hírek, hogy egyes román politikusok román (dákó-román) birodalom alakítását tervezik, s erröl Franciaországban nyíltan beszélnek. A másik az, hogy E. Murgut, a magyar országgyủlés követét, Krassóban vajdává vảlasztották. Emellett az egyik román követ a magyar arisztokratáknak a románok ellen elkövetett „múltbéli büneit” emlitve, arról is panaszt tett, hogy a megadott jogok nagy része csak papíroson áll. „Ha meg van adva minden jog, hol vannak az oláh föispánok?"

Kossuth nagy beszédben válaszolt a felmerülő kérdésekre, kiemelve, hogy tudomảsa szerint „Magyarországot lakó kủlönféle népfajok között olyan szellemủ s irảnyzatủ agitátiók történtek, mellyek a közös jog, szabadság, s a haza egységével ellenkeznek."5l Aztán az erdélyi románok múltbéli panaszainak jogosságát elismerve, csodálkozását fejezte ki amiatt, hogy a régi „,bünök” (célzás a három nemzet és a négy bevett vallás rendszerére) „alapjản most kell a hont veszélyeztetỏ agitációknak történni, mikor letétetett az első szó és talap a sérelmek orvoslására"; $s$ azért, mert 24 óra alatt nem lehetett a régi bajokat orvosolni. De nem fejezte be fejtegetését anélkül, hogy ki ne fejtse: „minden lépéshez, melly a múltak bủneinek orvoslására vezethet, hozzảjảrulok szívesen, de kérem a követ urakat, akik éppen közelebbi viszonyaiknál fogva jobban ismerik a körülményeket, legyenek szívesek minket tájékoztatni, hogy mit tegyünk, de ne álljanak elé olyan kívánsággal, amely dismembratiora vezethet. A magyarok az oláhval s az oláhnak a magyar testvéries egyesülésben van mindegyiknek boldog jövője, nem pedig, ha egyik el hagyja magát ámítani a másiknak elnyomására." 52

Maradjunk az előbbi politikai kinyilatkoztatásnál.

Kossuth a mủlt minden hibáját hajlandó orvosolni, s arra kéri a magyar országgyülés román képviselőit (akik egyébként szóvá tettek minden Erdélyből érkezỏ olyan hírt, amely

\footnotetext{
${ }^{18}$ Országgyủlési Könyvtár Gyũjtemény 1848-49. Jegyzőkönyv. 51. sz.

${ }^{49}$ Uo.

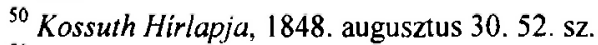

\$1 A. G. Golescu az erdélyi román komité tagjaihoz ín levelében a magyarok ellen fegyveres harcot javasolt, valamint azt, hogy csatlakozzanak Jellasichoz. Ion Maiorescu Frankfurtban ausztro-dákóromán tervet terjesztett elö. (Tóth Zoltán: A magyar-román szövetség kérdése 1848-ban. Századok, 1848. 272-273.)

${ }^{52}$ Kossuth Hirlapja. 1848. augusztus 30. 52. sz. 
valamely román embert ért sérelemröl szólt), hogy „legyenek szívesek minket tájékoztatni, hogy mit tegyünk". És ezzel tulajdonképp felkérte Kossuth a román követeket, hogy legyenek segítségére a nemzetiségi problémák rendezésében. Kossuth maga is aktiv szerepet vállalt az erdélyi unió törvényességének biztosításában, s az unióbizottságot sürgette a szükséges törvényjavaslatok benyújtására. A képviselöház szeptember 12-i ülésében bejelentette, hogy Pálffy János követ „szíves közremunkálásával” áttekintette azokat a törvényes intézkedéseket, amelyeket Erdélyre nézve kivételesen szükségesnek tart, $\mathrm{s}$ azokat az országgyülés elnökéhez benyújtották. Kérte: a törvényhozás nyomtassa ki a javaslatokat, hogy azokat lehessen tanácskozásra bocsátani. ${ }^{53}$

Az unióbizottság által kidolgozott $s$ a kormány által benyújtott törvényjavaslatcsomag vitájára szeptember 15.-én került sor. A vitára, elfogadásra benyújtott törvénycsomag megfelelt Kossuth politikájának: Erdély polgárosításának az unió által. Ennek során külön hangsúlyt kapott a jobbágyfelszabadító törvények következetes alkalmazása. Vita e körül nem volt, annál inkább szólt a közigazgatási törvényról.

Nevezett törvénycikk elöírta a kormánynak, hogy alkalmazzon megfelelö számban erdélyi tisztségviselőket is. Nyáry Pál azt is szükségesnek látta, hogy románok alkalmazását külön is említse meg a törvény. Támogatta őt Sigismund Pop (Pap Zsigmond) román követ is. E kitétel ellenzői azzal érveltek: alighogy sikerül a három nemzet és négy bevett vallás rendszerét megszüntetni, s máris újra kezdenék a jogok megosztását, mert ha a románokat külön is megemlíti a törvény, hasonló követelésekkel léphetnek fel más nemzetiségek is: „volt 3 nemzet, 4 vallás - ez a hét bủn” -, nem kell ezt újabbal megtoldani. Érveik közül az sem hiányzott, hogy nemcsak a románok voltak jogukból kirekesztve, hanem a magyar parasztok is, tehát őket is külön meg kellene említeni a hivatalviselési jogot illetően.

Kossuth többször is felszólalt a vitában, amit az is indokolt, hogy Erdélyböl ismét rossz hírek érkeztek magyarellenes agitációról, románok elfogatásáról. Minden szónoki tehetségét latba vetve, valósággal hitet tett a magyar és román nemzet közös érdekei mellett. Érdemesnek tartjuk hosszabban idézni: „Elöre tudtul adom a háznak, miként én azon meggyőződésből kiindulva, mellyet már több ízben kijelentettem, hogy ti. Európának minden népiségei között a magyar és az oláh az, melly, ha élni akar, hivatva van egymás irányában a legnagyobb rokonszenvvel egyetértésben lenni, ezen meggyőződésből indulva és azt remélve, hogy román ajkú polgártársaink között is sokan vannak, kik ezen meggyőződést osztják, akik ezen meggyőződésnek a román ajkúaknál sikert szerezni, s részükröl is közremunkálni hazafiúi kötelességöknek ismerik; azon reményben, hogy ezen meggyőződés vérré válik náluk is, szinte ủgy, mint vérré vált nálunk: nagyon hajlandó volnék megkísérteni, hogy az eddig történt zavargások emlékezetére a feledékenység fátyola borittassék." Kéri a házat, szólitsa fel a nádort, bocsássa szabadon az elfogott románokat. ${ }^{34}$

Nincs semmi okunk kételkedni Kossuth beszédének őszinteségében: úgy lảtta, hogy a szlávság s németség között élő két népnek össze kell fognia a rájuk leselkedő veszély elhárítására. Közvetíteni próbált a radikális követeléseket hangoztató román követek $\mathrm{s}$ a magyar liberálisok között. És elment addig, hogy az utỏbbiak ellenében Nyảry javaslatát támogatta; nevezetesen, hogy a törvényjavaslat külön is emelje ki a románok támogatását, „mert ha van valakinek panasza a múltra nézve, csak a románoknak van, tehát csak nekik kell megnyugtatás is". Természetesen Kossuth nagyon jól tudta, hogy a románsảg ugyanazon okok miatt maradt ki a rendi struktủrákból, mint a magyar parasztság, csakhogy a politikumnak most nagyobb volt a súlya, mint a tudományos realitások hangoztatásảnak.

53 „Erdélyre nézve amely törvényes intézkedéseket kitételesen szükségesnek tartok, azokat különösen Pálfi képviselő úrnak szíves közremunkálásával bevégeztük, $\mathrm{s}$ az elnökségnek be is adtuk." Kossuth Hirlapja, 1848. szeptember 16. 67. sz.

${ }^{54}$ Uo. 
A javaslatot eredetileg Sigismund Pop határvidéki képviselö fogalmazta meg, s Kossuth támogatta. ${ }^{55}$

A parlamenti többség azonban leszavazta Kossuth javaslatát $s$ a törvényjavaslatot a régebbi formájában fogadta el: „Erdélyi törvényekben gyakorlott és az ottani viszonyokat ismerö egyének mindenik ministeriumban a szükséges számmal fognak alkalmaztatni."

Bár Jellasič szeptember 11 .-i támadása nagyon megzavarta a törvényhozó munkát, az mégsem szünt meg teljesen: szeptember 19.-én az unióbizottság elfogadott egy olyan nemzetiségi törvénytervezetet, amelyet a magyar országgyülés román képviselöi dolgoztak ki. Ez kijelenti, hogy a románok templomaikban, egyházi ügyeikben, az elemi és felsöbb iskolákban saját román nyelvüket háboritatlanul használják; a megyékben és a székekben a tanácskozásokban jogukban áll anyanyelvükön felszólalni; románokat ,igazságos arányban” alkalmaznak a közigazgatásban. A 16 . paragrafus kimondja: „Mindazon jogokban s kedvezményekben, mellyeket e hon más nemzetei bírnak, vagy ezután törvényhozási úton nyerendenek, a románok is részesítendök" .57

Ha a fenti törvényjavaslatot a Wesselényi-féle elöterjesztéssel összevetjük, szembetünő a változás; most már nem csak az elemi oktatás, hanem felsőbb iskolák nyelve is lehet a kisebbségi nyelv, a megyékben és a székekben az anyanyelvűség általános lehet, $\mathrm{s}$ nyíltan kimondja: a románokat minden jog megilleti, amellyel mások rendelkeznek.

Mindezek részét képezik majd az 1849-es nemzetiségi törvénynek. S hogy a fenti elöterjesztésekböl 1848-ban nem lett elfogadott törvénycikk, az véleményünk szerint nem Kossuthon $\mathrm{s}$ nem is a magyar országgyúlésen múlt, hanem elsősorban - de korántsem kizárólag - az 1848. évi öszi háborús konfliktusok következménye volt. Azonban az elöterjesztett törvényjavaslatok mindegyike araszolást jelentett az európai történetben elsőként elfogadott, 1849. évi nemzetiségi törvény felé.

\section{A polgárháború kérdései. Kossuth álláspontja}

Erdély 1848-49-i történetének egy másik bonyolult és vitatott kérdése az, hogy az 1848 márciusában békésen kezdődött mozgalom hogyan alakult át véres pusztitó polgárháborúvá. Mind a magyar, mind a román és szász törtẻnetírás sokat foglalkozott az említett kérdéssel, de egymástól eltérő, sőt általában egymásnak ellentmondó válaszok születtek. A román történetírás Magyarország és Erdély uniójában, újraegyesitésében jelöli meg a drámai konfliktus fỏ okát, s elinditójának az október közepén tartott Székely Nemzeti Gyưlést tartja. Ettől a régebbi szász történetírás álláspontja nem sokban különbözik.

A magyar kutatók többsége nem vonja kétségbe, hogy az unió kimondása nemzetiségi feszültségeket is kiváltott, de szerintünk ez önmagában nem szükségszerüen vezetett polgárháborúhoz, hiszen a magyar vezetés - amint az elözőekben láttuk bizonyithatóan folyamatosan kereste a békés kiegyenlitődés lehetőségeit. Ezt a célt szolgálta a románok áltâl annyit sérelmezett feudális-rendi törvények eltörlése, s helyettük a polgári

55 „Ha múltak viszonyai ollyanok voltak volna, hogy Erdélyben a román ajkúak azelött is tőkéletesen egyenlöknek mondhatták volna magokat a három nemzettel, akkor Pap Zsigmond indítványát nem pártolnám, mert akor azon kifejezés, melly a tơrvényczikkben foglaltatík, tơkéletesen elég. Hanem miután csakugyan úgy áll a dolog, hogy Erdélyben, ha van valakinek panasza múltra nézve, csak román ajkúaknak van, tehát csak nekik kell megnyugtatás is. A javaslat tökéletesen kielégítö, de ha nem tơbb, mint ami abban van, pleonasmust (szóismétlést) csinálok inkảbb, ha megnyugtatảst szerezhetek vele. azt lehetne tehát a §̧-ba tenni: 'a román ajkủakból is'." (KLÖM. XII. 939.)

${ }^{56}$ Országgyülési irományjegyzék. 167

${ }^{57}$ Márki Sándor: i.m. 357. 
szabadságjogokat biztosító áprilisi törvények elfogadảsa, majd az erdélyi orszảggyülés azonos szellemü törvényei, amelyekkel a románság nyert a legtöbbet, hiszen a felszabadult jobbảgyok többsége román volt. Amit Orosz István a jobbágyfelszabadításról ír, az Erdélyre éppúgy érvényes volt, mint Magyarországra nézve: "gyökeres társadalmi fordulat következett be", mert leomlottak azok a válaszfalak, amelyek az állampolgári jogok tekintetében a feudális rend idején keletkeztek. ${ }^{58}$

Hogy a nemzetiségi törvény miért csak a szabadságharc utolsó heteiben jöhetett létre, annak okát mindenekelött a császári hatalom és Magyarország közt szeptemberben beállt kedvezötlen fordulat következményeiben kell keresnünk. Ugyanis ez a fordulat Erdélyt a polgárháború küszöbére taszította: megkezdödött a magyar nemzetörségek lefegyverzése, a magyar nemesek és hivatalnokok összeszedése, táborba szállítása s megkínzása. Súlyosbító körülmény volt, hogy a magyarság lefegyverzését a császári katonai föparancsnok, Puchner tábornok a román és a szász fegyveres felkelésre bízta. ${ }^{59}$ Hogy mi volt a császári hatalom célja, azt Kosáry Domokos akadémikus szabatosan megfogalmazta. Öt idézzük: „De akármennyire adva is volt egy bizonyos ellentét a Duna-medence nemzetiségei között, a bécsi ellenforradalmat terheli a felelősség, hogy a saját érdekében kihasználta és a fegyveres összetüzésig hevitette ezt az ellentétet. Neki nem az volt a fontos, hogy egyik vagy másik nacionalizmus elérje, amit akar, hanem az, hogy a magyarok ellen szövetségeseket szerezzen." ${ }^{60}$ A szövetséges had nagy részét a felkelö parasztság alkotta.

A fegyelmezetlen és sok esetben fegyelmezhetetlen felkelő parasztság októberben és novemberben féktelen dühvel vetette rá magát a magyar földesurak mellett a magyar közösségekre és egyházakra. Ennek során nagy számú magyar polgári lakost pusztítottak el, elsösorban Alsó-Fehér megyében és a Mezöségen, miközben a vármegyékben magyar nemesi udvarházak és kastélyok többségét kirabolták és felégették. Bár a román falvak népessége is jelentös veszteségeket szenvedett, 1848 öszén és telén a magyar polgári lakosság veszteségei összehasonlithatatlanul nagyobbak voltak.

Mint ismeretes, Bem 1848. december végén kezdődött erdélyi hadjárata új fordulatot idézett elö Erdély helyzetében: rendkívül gyors ellentámadással szorította ki az ellenséget Erdélyből. Ezzel egyidőben a magyar vezetésnek tisztáznia kellett, hogy milyen politikảt folytasson a polgárháborús Erdélyben. Mivel ez a kérdés kevẻssé ismert, ki kell térnünk rá.

A nehézség abból adódik, hogy történetírásunk mindmáig nem tárta föl kellően az 1849-es év történetét Erdélyben. Viszonylag sokat foglalkozott Bem hadjáratának leírásával, Kossuth és Bem, valamint Csány kormánybiztos és Bem tábornok viszonyának immár szokványossá vált bemutatásával. Sok bírálat érte Kossuth és Csány nemzetiségi politikáját, $\mathrm{s}$ még több elismerés jutott Bem amnesztiát hirdetỏ állásfoglalásának. Kossuth politikảjảban valóban voltak ellentmondások a nemzetiségekkel való tárgyalások során, de látnunk kell azt is, hogy politikáját mennyire befolyásolták a belső körülmények, például a román felkelök által elkövetett vérengzések $\mathrm{s}$ az, hogy a szász vezetők kezdeményezték a cári beavatkozást Erdélyben. Azt is figyelembe kell venni, hogy Kossuth 1849-i politikájában időnként nem jelentéktelen változások következtek be.

Fokozottabb mértékben kell kutatnunk 1849 történetét azért is, hogy a román történetírảs egyoldalúságait tények bemutatása által lehessen ellensúlyozni. A román történetkutatók, egy-két kivételtöl eltekintve, mártírológiát írnak a polgárháború román áldozatairól, de rendszerint elhallgatják vagy minimalizálják a magyar áldozatokat. Emellett különbözö jellegü eseményeket mosnak egybe: igy a polgárhảborủ idején elkövetett közbủntényekért indított, magyar hatósági felelösségre vonást a vadászcsapatok

\$8 Orosz István: A felszabadult jobbảgy problémái az ủj társadalmi rendben. Jobbágyfelszabadítás 1818. Budapest, 1998. 54.

${ }^{59}$ Egyed Ákos: Erdély 1848-1849. 1. Csikszereda, 1998.

${ }^{60}$ Kosáry Domokos: Ĺjjáépités és polgárosodás. 1711-1867, Budapest, 1990. 345 
tevékenységével, de az utóbbiban sem látnak különbséget e csapatoknak népfelkelökkel vívott összecsapásai, illetőleg a román falvak lefegyverzése során végrehajtott akcióik között. S ráadásul a vadászcsapatok által elkövetett egyes túlkapásokért, hatáskörük túllépéséért is a magyar kormányzat föbb vezetöit, Kossuthot és Csányt teszik felelössé.

Egyik kérdésünk tehát az, hogy Bem amnesztiapolitikája egyéni kezdeményezés volte, vagy a magyar kormányé, pontosabban a Kossuthé is. Kérdésünkre választ kapunk, ha tekintetbe vesszük, hogy Bem az 1848. december 6.-án Nagyváradon kibocsátott kiáltványának alapelveit, mint „az ország kormányától biztosított jogok”-at hirdette meg. Ebben a következő jogokról biztosítja Erdély népeit: „Minden lakosok nemzetiség, vallásés rangkülönbség nélkül egyenlök és minden hivatalok viselésére ugyanazon jogaik vannak, ha az álladalomnak becsületesen és hüségesen szolgálnak és a szükséges képességekkel bírnak." És tovább: „Jóllehet a magyar nyelv az országgyülés nyelvének vétetett fel, minden más népségek nemzetiségöket megtartják, és magok belső ügyeikben a magyar nyelv mellett tulajdon nyelvökkel élhetnek. Minden valláskülönbség nélkül a kormány által ugyanazon oltalomban részesülnek." 61

Nem lehet vitás, hogy amikor Kossuth Bem tábornokot az erdélyi haderő föparancsnokává kinevezte, közölte saját erdélyi vonatkozású politikảjảnak alapelveit, s ezáltal annak közzétételére fel is hatalmazta a tábornokot. Nem véletlen tehát, hogy Bem tábornok szükségesnek tartotta hangoztatni: amit ígér, a magyar kormány nevében ígéri. Bem a Kolozsvárt 1848. december 27.-én három nyelven közölt kiáltványában pontosította az erdélyi politikát: „Mindennemü politikai vétkekért általános bocsánat biztosíttatik az egész országra nézve”, de siet hozzáfüzni, hogy az „alkotmảnyszerü kormány ellen” ezután elkövetendö mindennemủ újabb politikai vétség haditörvényszék alá tartozik, akárcsak a fegyverek rejtegetése. ${ }^{62}$

Mindez nem állt szemben Kossuth $s$ az Erdélybe küldött Beöthy Ödön fökormánybiztos politikájával; nem fogadhatjuk tehát el az egyébként kiváló Bem-kutató Kovács Endrének azon állitását, hogy a kolozsvári kiáltvánnyal megkezdödött „Bem önálló, kormánytól fugggetlen nemzetiségpolitikảja". A kolozsvári kiáltvány ugyanis csak szavakban különbözött a nagyváradi alapelvektöl, amelyeket - ismételjük - Bem a magyar kormány nevében tett közzé.

Mindezzel nem akarjuk azt a látszatot kelteni, mintha Bem tábornok, illetve Beöthy fökormánybiztos intézkedései teljesen egybeestek volna. Ez már csak azért sem lehetett így, mert - kinevezésük értelmében - Bem a katonai, Beöthy a polgári ügyekért volt felelös. Bem feladata Erdély visszavétele, Beöthyé a belbéke helyreállítása és az uniós törvény alkalmazása volt. Bem nem tért ki az 1848 öszén elkövetett büntényekre, de amnesztiájảban világosan kijelentette, hogy kegyelemben a politikai vétségek elkövetöi részesülnek. Beöthy ugyan a január 6.-i rendeletében nem szólt amnesztiáról, de ,a törvényes rend és alkotmányos szabadság" visszaállitását nem terror útján vélte elérhetőnek, hanem a "meggyözés, kibékítés" eszközével, $\mathrm{s}$ a belbéke érdekében ekkor még kijelentése szerint a felkelök által okozott károkat is a kormány becsült ảron hajlandó kifizetni. A felállítandó vadászcsapatok feladata sem a bosszúállás az elkövetett atrocitások miatt, hanem "az oláhajkú nép lefegyverzése és az elrablott portékák, hol azok találhatók, visszaszerzése". De szó sincs még megtorlásról, hiszen Beöthy arra figyelmezteti az illetékeseket, hogy „ki erkölcsi tisztaságban és becsületességben nem bízik, e sereghez be ne áljon, mert a magyar nemzet egyedüli feladata, bármi méltatlanságot és polgáriasság elleni tényt követtek légyen

\footnotetext{
${ }^{61}$ Honvéd, 1848. december 28. 1. s7.

${ }^{62} \mathrm{Uo}$.
} 
is el ellene, hasonló mértékkel vissza nem fizetni, mert ezt sem historiai nevezetessége, sem világszerte ismert becsületes jelleme meg nem engedi." ${ }^{63}$

Sokat mondó tény az is, hogy Czetz alezredes, (később tábornok) a Tordán állomásozó különítmény parancsnoka azt kérte Beöthytöl: váltsa fel a föként Kolozsvárt és Nagyenyeden toborzott önkéntesekböl álló 11 . zászlóaljat egy távolabbi alakulattal, nehogy az elöbbi olyan tagjai, akiknek hozzátartozóit a román felkelök korábban elpusztították, bosszút álljanak. ${ }^{64}$

A rendelkezésünkre álló történeti források újraértelmezése alapján úgy látjuk, hogy amikor az erdélyi hadjárat elindult, a magyar szabadságharc erdélyi ügyekben illetékes vezetöi: Kossuth, Bem, Beöthy és Czetz a lehetséges békés megoldásokat keresték s köztük ekkor még lényegi különbség e tekintetben nem ált fenn. Ezt a békésebb útkeresést zavarta meg az 1849. január 8-9.-én bekövetkezett nagyenyedi vérengzés, amely után valóban távolodik egymástól Kossuth és az új erdélyi fökormánybiztos, Csány László, illetve Bem politikája.

Nagyenyeden mintegy 800 magyar polgári lakost öltek meg a felkelök, $s$ legalább kétezren menekültek a közeli erdökbe, falvakba és városokba. A lakóházak nagy része leégett, a híres Bethlen-kollégium gyüjteményeit, könyvtárát széthordták. Pár nap múltán a felkelök Alsójára, Hari, Nagylak, Borosbenedek magyarságára vetették magukat és közülük sokat elpusztítottak. ${ }^{65}$ A román csapatok Axente Sever parancsnoksága alatt állottak, akit a kortársak Enyedért is felelössé tettek.

Az enyedi, járai és más hasonló események nagy megdöbbenést váltottak ki a magyar politikusok körében, akik meg voltak gyözödve, hogy a román felkelök Erdély teljes magyar lakosságát ki akarják irtani. Ezért egyre többen követelték az erélyesebb fellépést és a felelősségre vonást nemcsak az újabb, de az 1848 öszén és telén elkövetett atrocitások és pusztítások miatt is. Bem tábornok az utóbbival, vagyis a visszamenöleges felelösségre vonással nem értett egyet.

Elsöként az eddig nagy mérsékletet tanúsító Czetz alezredes kéri felettesétöl az erélyesebb intézkedéseket. Az enyedi események hatását kell látnunk a fökormánybiztoscserében is: Beöthy betegségére hivatkozott, azért mondott le, de voltaképpen mégis azért, mert Enyed tragédiája miatt lelkiismereti válságba került. Kossuth elfogadta a lemondását és helyére Csány Lászlót, a Jellasiic ellen küzdő seregek eddigi kormánybiztosát nevezte ki. A kinevezést bejelentő 1849. január 27.-i rendelet szerint ,az országos biztos vállára fektetett nagyszerủ feladat - egy lázadók által feldúlt országnak a magyar törvény iránti engedelmesség alapján reorganizációja, biztosítása, pacifikációja és rendbehozatala". Kossuth nem mulasztotta el hangsúlyozni, hogy Erdélyben a magyar nemzet jövöjének biztosítása ne jelentse a mások feletti zsarnokságot. Meg kell nyerni a nép szimpátiáját a magyar alkotmányos kormányzás és az önállóság iránt. Amikor Kossuth Csányt teljhatalommal ruházta fel, a követendỏ politikát így jelölte ki: „Kegyelem vagy kérlelhetetlen igazság vezesse önt a bünök büntetése körül, ezt a körülmények $s$ ön belátása határozandjảk. De legyen kegyelem, legyen igazsảg, minden esetre erő legyen." ${ }^{\circ 6}$ Kossuth elöirta Csánynak a román határörvidék lefegyverzésèt, $s$ arra kérte, hogy Bem tábornokkal a lehető legiobb viszonyt tartsa fenn.

Csány számára a legnehezebb feladatot a román népfelkelök lefegyverzése, a polgárháborúban elkövetett atrocitások tetteseinek összeszedése jelentette. A fökormánybiztos igyekezett a lefegyverzést és az abban közremüködő csapatok fellépéseit ellenőrzés alatt tartani. Jellemzőnek tartjuk az Egloffstein tordai térparancsnokhoz küldött

\footnotetext{
${ }^{63} \mathrm{MOL}$. OHB. $701 / 1849$

${ }^{64}$ Az MTA Könyvtára. Kézirattár. Csány Lvt. 4925. doboz, 342911841. sz.

${ }^{65}$ Egyed Ákos: I. m. II. 24-38.

${ }^{66}$ KLÖM XIV. 249-250. 
utasítását: Legyen gondja, hogy „a fegyveres erö részéröl semmi kihágás ne történjék, $s$ ha történik, szigorúan büntessék. Ez lévén megtartandó azon helyekre is, melyek meghódoltak. $\mathrm{Ez}$ a leghatékonyabb módszer a népet a lázadásoktól elvonni s ügyünkhöz csatolni, ha ti. látja a nép, hogy megtérése esetén személy és vagyon bátorságában élhet."

Erdély visszavétele után Kossuth Erdély polgárositását írta elő Csảny főkormánybiztosnak. Nem árt azonban hangsúlyoznunk, hogy Kossuth Erdély-politikájában - erről már esett szó - változások figyelhetők meg 1849 különböző időszakaiban. Az év elején, januárban az erdélyi sajátosságok lehetőség szerinti kímélését ajảnlotta Csảny kormánybiztosnak, 1849 áprilisában viszont a közigazgatás átszervezésének szükségességét hangsúlyozta: „Erdélyt organizálni kell. Csak ezáltal testesülhet az unió valósággá. Institúcióinak harmóniába kell hozatni Magyarországgal, különben nincs állandóság. Nemzetiségek $s$ vallások, mint státusorganizmus alapjai, kábaság. Ennek meg kell szünni, $s$ a megszünést új territoriális felosztással garantírozni." ${ }^{67}$ Itt jegyezzük meg, hogy ettől a kimondottan centralizációs álláspontról jutott el a Bălcescuval és Cezar Bolliac-kal megkötött magyar-román megbékélési tervezetig, aztán az 1848. július 28-án elfogadott nemzetiségi törvényig, majd az emigrációban a Duna konföderáció tervéig, amelyben Erdély maga határozhatott volna sorsáról. ${ }^{68}$

$\mathrm{Az}$ átszervezés éppen csak elkezdődött, de a közbejött események miatt érdemi változtatás a vármegyék, székely székek s szász székek szerinti igazgatảsban nem történt.

A társadalmi átalakulások viszont alapvetỏek voltak. A jobbágyok szabad paraszti státust kaptak, $s$ egy részük (kisebb rétegük) választói jogot is nyert. A nemesek privilégiumai megszủntek, $\mathrm{s}$ adófizető polgảrokká váltak. A polgári átrendeződésnek sok akadálya merült fel, hiszen Erdély 1848 októbere óta hảborúskodás színtere volt. A polgárháború, különösen a vármegyei területeken hatalmas pusztítást végzett a magyar nemesség és tisztviselők, sőt az egyszerủ polgári lakosok soraiban is, számos vidéken rombolta le a településeket. Kossuth ezután sem a kollektív bosszúállás politikájảt követelte, hanem a megbékélését.

Azonban a cári beavatkozással ismét a fegyverek foglalták el a fỏ helyet a békés munka helyett. Majd a világosi és zsibói fegyverletétel után a megtorlás és a Habsburghatalom katonai diktatúrája teremtett hamisíthatatlan ellenforradalmi helyzetet.

Kossuth ekkor még abban reménykedett, hogy a hatalmi konfliktusok kihasználása által újra kezdhető a fúggetlenségi harc, ám Ausztria katonai kapitulációja Franciaország majd Olaszország elött, Kossuth számára is lezárta a diplomáciai megoldảsok lehetőségét.

Az emigrációban alkalma volt átgondolni a történeteket, $s$ az ott keletkezett irataiban visszatekintett 1848-1849-re. Ő akkor több évtized távlatából mérlegelve a mủltat, a 48-as forradalom eredményeit - amint már ejtettünk szót róla - úgy látta, hogy az átalakitások nem szolgáltathattak okot a hatalomnak erőszakhoz nyúlni a magyar forradalom ellen, hiszen ,a progresszív fejlödés történelmi törvényének határai közt maradtunk”. A véghezvitt reformokkal igazsảgot kellett szolgảltatni a népnek alkotmányos alapon.

Kötelességtevésben Kossuth mindig az élen járt, és élen járt abban is, hogy összefogja a magyar nemzet legjobb erőit a nagy közös cél, a haza jövője érdekében. Ezért Kossuth nem elválaszt, hanem összefog, egyesit.

${ }^{67}$ Kossuth Lajos: Irások és beszédek 1848-1849-böl. Szerk. Katona Tamás. Budapest. 1987. 343

${ }^{68}$ Spira György: Kossuth és alkotmányterve. Debrecen. 1989. 


\section{Kossuth Lajos és a székelyek katonai szolgálata 1848-1849-ben}

A magyar forradalom 1848 márciusában vẻr nélkül, bẻkés eszközökkel elérte föbb céljait, azokat az április 11 -én kihirdetett, király által szentesített törvények megerősítették. Azonban a történelmi jelentőségủ, átütő magyar sikereknek számos ellenzője, sőt ellensége készülődött arra, hogy Magyarország önállósági törekvéseit megakadályozza. Nem érdektelen, hogy a fizikailag már évek óta vakságra ítélt, de politikailag mégis igen "messze látó" Wesselényi Miklós már a forradalom első napjaiban, 1848. március 23-án a "lelkesültség, öröm viharában" fogant Kossuth Lajosnak küldött levelében a Magyarországra leselkedő veszedelmekről is szól. Eszerint az osztrák abszolutizmus "átkos rendszerének" fennálló olyan képződményeiről, mint a hierarchia, oligarchia „,bureaucratia", valamint a „fenyegető Európa-szertei szláv kombinatiok" az "öröm mámorában" sem szabad megfeledkezni. ${ }^{69} \mathrm{~S}$ továbbmenve, rövidesen, április 18-án a pesti "Radical Kör"ben elhangzott beszédében már fegyverre hívta az arra képes férfiakat a haza védelmére. Hatására a "Radical Kör" petíciót intézett a kormányhoz a magyar haderő megalakitása érdekében. $\mathrm{Az}$ is figyelmet érdemel, hogy a petíció aláírói között első helyen állt a Kör elnökének, Kossuth Lajos támogatójának és barátjának, az erdẻlyi Teleki Lászlónak a neve. $^{70}$

A magyar forradalom vezetése tudatában volt annak, hegy a leselkedő, sőt az országhatár mentén már-már fellépő veszedelmek elleni védekezés leghatékonyabb eszköze az önálló magyar haderö. Tehát annak megalakítása elodázhatatlan feladat, azẻrt is, mert a márciusi változásokat voltaképpen ellenző bécsi hadügyi vezetés továbbra is parancsokat osztogatott a Magyarországon levő katonai hatóságoknak, holott ez mảr a kihirdetett törvények értelmében a magyar hadügyminisztérium jogkörébe tartozott. Azonban haderő létrehozása nem lehetett könnyü feladat, hiszen a semmiböl kellett kiindulnia a. szervezőknek, mert korábban Magyarországnak nem volt saját fegyvere s ereje. S amellett, hogy az anyagi, pénzügyi feltételeket is biztositani kellett, gondot okozott az is, hogy a Batthyány-kormány hadügyminisztere. Mészáros Lázár huszárezredes ${ }^{71}$ sokáig távol volt. mert Olaszországban a Radeczky tábornagy hadseregében teljesített szolgálatot. De a haderőszervezéssel késlekedni nem lehetett, ezért Batthyány ideiglenes hadügyminiszterként látott hozzá az önálló haderö létrehozásához. Ebből Kossuth Lajos böven kivette a részét és nemcsak pénzügyminiszterként, hanem mint Magyarország önảllóságának, kivivott szabadsága megvédésének elkötelezett politikusa is: Kossuth és Batthyány nemcsak Mészáros Lázár hazatértéig maradtak hadszervezők, hanem azután is, mert az első hadügyminiszternek a szervezỏmunka nem tartozott az erényei közé. ${ }^{72}$

A szinte legyőzhetetlennek látszó számos probléma ellenére az önảlló magyar honvédséget a kormány létrehozta $s$ az kétségtelenül a magyar forradalom legnagyobb eredményeinek egyike volt. Olyan haderőt alakitottak, amely majdnem másfél éven keresztül sikerrel védelmezte Magyarországot, s végül is csak a két nagyhatalom: Ausztria és Oroszország, vaiamint a szövetségükbe vont nemzetiségek tulereje volt kẻpes leverni.

Tanulmányunk azt a kérdést kutatja, hogyan alakult a székelység katonai szolgálata 1848-1849-ben a magyar honvédség megalakulásában, s milyen szerepe volt ezekben

\footnotetext{
${ }^{69}$ Wesselényi Kossuth Lajoshoz. 1848. március 23. Állami Levéltár Kolozsvár. Wesselényi Miklós levelezése. Wesselényi Miklós levélmásolatai; 34. kötet, 60-64.1.

${ }^{70}$ Szilágyi Sándor: A magyar forradalom férfiai 1848/1849-böl. Pest, 1850

'I Öt Kossuth ajảnlotta hadügyminiszternek.

${ }^{72}$ Hermann Róbert: 1848-1849. A szabadságharc hadtörténete. Bp. 2001. 22-23. 
Kossuth Lajosnak. Bár erröl a kérdésröl több tanulmányt is közöltem, ${ }^{75}$ újabb kutatásaim alapján szélesebb összefüggéseiben vizsgálom itt következỏ tanulmányomban ezt a kérdést.

De mielött ezekre rátérnénk, legyen szabad rövid kitẻröt tennem a Kossuth-kérdés szélesebb terulletére.

A magyar történetírás - helyesen - kategorikus különbséget tesz a forradalom és a szabadságharc között. A történetírás 1848. március 15.-töl 1848. szeptember 11-ig, Jellasic Magyarország elleni támadásig számítja a forradalmat. Utóbbihoz köti a szabadságharc kezdetét, amely 1849. augusztus 13-ig, a világosi fegyverletételig tartott. Ez a periodizálás a meghatározó jelentőségủ eseményeket és folyamatokat tekintve helyes és szükséges is, hiszen a nagy átrendeződések a szeptember 11-i fordulatig már megtörténtek, tehát a forradalom sikeres volt, győzött. A szabadságharc vállalását az ország önállóságának megvédése tette szükségessé.

A fentiekkel kapcsolatban mégis hangsúlyoznom kell: a szélesebb közvélemény akkor nem tehetett $s$ nem is tett olyan különbséget a forradalom és szabadsảgharc között, mint a későbbi történetírás, s már a forradalom kezdeteit is hajlamos volt olyan szabadságkủzdelemnek felfogni, amely a nemzeti elnyomást megtestesitő Ausztria ellen irányul. Ezt sugallta kétségkívül Petőfi Nemzeti dalónak szelleme, a 12 pont, és erre mutattak az áprilisi törvények is. Ilyen felfogás következménye $s$ kifejeződése volt a Habsburg-hatalmi jelek és jelképek megrohanása számōs helyen, azok eltávolítása s helyettük magyar nemzeti szimbólumok kitüzése.

Kossuth határozottan ellenezte a "Petőfi-féle forradalom" gondolatát és módszereit, ő az átalakulás törvényes, alkotmányos útját választotta, egyébkẻnt egyedülálló sikerrel egész Európában. Pozsonyban a Habsburg-birodalom uralkodója jelenlétében hirdették ki az általa magyar királyként megerősitett törvényeket, amelyek előírjảk Magyarország önálló állami létét $\mathrm{s}$ a rendi-feüdális állam $\mathrm{s}$ társadalmi rendszer megszüntetését, kodifikálták a polgári rendszer kerettörvényeit. Ezért visszaemlékezésében Kossuth nyomatékosan hangsúlyozta: 1848 tavaszán "nekünk forradalmat csinálni eszünk ágában sem volt, akkor mi csak reformokat akartunk $s$ azokat a király szentesitése mellett alkotmányos úton keresztül is vittuk" "7t Nem mintha ô a forradalmat elvileg elutasította volna, hanem azért, mert csak "végeszközként" volt hajlandó azt elfogadni.

De bármennyire védte a törvényességét, $s$ bármennyire el akarta kerülni 1848 tavaszán még látszatát is annak, hogy ő népforradalom vezére kíván lenni, a magyarság többsége Kossuthot a Habsburg-ellenes (az akkori felfogás szerint osztrákellenes) magyar nemzeti szabadságküzdelem és a népakarat vezetőjének tekintette. Elsősorban benne látta a magyar nemzet szabadságának s méltóságának letẻteményesét és megalkuvás nélküli biztosítékát. Ezért volt hajlandó hívó szónoklataira a magyar nép követni öt. Ezért írhatta Pálffy János, Udvarhelyszék liberális gondolkozásủ politikusa, Kossuth politikảjának támogatója, majd kíméletlen bírálója - túlzással, de lényegét tekintve mégsem teljesen alaptalanul: az 1848-as forradalmat Kossuth ,egymaga csinálta”. Pálffy ezeket írta: ..4 magyar nemzet három század alatt sem felejtette, $s$ nem is fogja soha felejteni azelötti függetlenségét, önálló hatalmát és nagyságát; szóval históriai mủltjảt, mely után epedve, mindig fiatal vággyal, fájdalom és bosszúval telve tekint azon idöbe, melyben e drága kincse elraboltatott, s mert a rabló az osztrák, gyúlöli uralmát, hagyván azt örökségül nemzedékröl nemzedékre, valamint kötelességet is, mint jogos cselekedetet az erőszak ellen, lerázni az idegen igát bármikor nyiljék alkalom rá, nem keresve újabb okot, állván századok óta az eredeti ok. E hagyományos gyülöltség az osztrák uralom ellen, $s$ a vágy, szabadulni tỏle, a nemzet vérébe ment által, jellemének kiegészitó részét alkotja.

${ }^{73}$ Egyed Ákos: Kossuth és a székelyek 1848-1849-ben. = Századok, 1994. 5. sz. 831-871.

${ }^{74}$ Kossuth Lajos: Irataim az emigrációból. II. Bp., 1881. 164. 
Kossuth Lajos, gyủlölve az osztrák uralmat mint magyar ember, s egyéni bosszúokból is, nemzeti gyülöltség képviselöjévé tette magát. $\bar{O}$ hangot és életet és nyilatkozást adott azon érzületnek, mely millió kebelben szunnyadott, de soha ki nem aludt".'j

\section{A székely határőri rendszer megszüntetésének kérdései}

Abból kell kiindulnunk, hogy a Habsburg-hatalom Mária Terézia politikája szerint 1764-ben, a határörrendszer létesítésekor, a Székelyfóldet tulajdonképpen kettészakította.

$\mathrm{Az}$ addigi szabad székelyeket besorjázta a katonai rendbe, a másik részének székelységét adóztatni kezdte. A határör rendszert eröszakkal kényszerítették a székelységre, az adóztatás pedig tulajdonképpen jogfosztást jelentett, hiszen a székelység a korábbi századokban a katonai szolgáltatásért adómentes volt. Ismeretes, hogy a hatảrỏr “övezet”-be került Csík-, Gyergyó- és Kászonszék, Háromszék, az Udvarhelyszékhez tartozó Bardóc fiúszék, valamint a távol fekvő Aranyosszék több települése. Udvarhelyszéken és Marosszéken nem szerveztek hatảrőri rendet. A katonásított rẻszen két gyalogezredet és egy huszárezredet hoztak létre, Marosszék és Udvarhelyszék szabad székelyei nem katonáskodtak, de - amint említettük - adófizetésre voltak kötelezve. Helyzetükből következően a határőr rendủek, illetve a szabad szẻkelyek nem kis mértẻkben eltérő módon viszonyultak a magyar forradalomhoz.

A székelység nagy részének felfogása abban viszont megegyezett, hogy a márciusi forradalmat kezdettől Habsburg-ellenes szabadságharcként értelmezte. Ennek az értelmezésnek a logikája szerint minden olyan sérelmet orvosolni kellett, amelyet az elnyomó Habsburg-hatalom okozott. Ehhez az első forradalmi napok hevében a székelység maga fogott hozzá. Gondolunk itt példảul a Habsburg-monarchia szimbólumainak eltávolítására s magyar jelképekkel való helyettesítésére. Ezentúl azonban az álláspontok különbözöségére kell figyelnünk. A 12 Pontban meghirdetett s Petöfi szellemében a “ magyar szabadság” uzzenete a határőri rend számára az volt, hogy le kell rázni az erőszakkal fenntartott katonai szolgálat terhét, ki kell szabadulni a hatảrőri rendszer szorításából. Mindebböl következöen már a forradalom elején a székelységre is ugyanolyan katonáskodási normákat kellett volna alkalmazni mint bármely más társadalmi kategória számára, de ezt nem sikerült megvalósítani. Ugyanis a magyar vezető osztály nem tartotta időszerünek a kész fegyveres erő megbontását, mert veszély fenyegette az országot.

A magyar politika veszélyérzete nem volt megalapozatlan: a szerb felkelés Délvidéken már április 24-én elkezdödött s nemsokára magyarellenes atrocitásokba torkollott. Válaszul a magyar kormány május 15-én a védelem megszervezése érdekében elhatározta: Szeged térségében katonai tábor alakul. Ezt követöen május 16-án Batthyány miniszterelnök felhívást tett közzé az első tíz zászlóalj megalakítására; a hadtörténetírás ezt a dátumot a honvédség tulajdonképpeni születésnapjaként tartja nyilván, bár a honvéd kifejezés valamivel késöbb terjedt el.

Erdélyben még nem kezdödhetett el a honvédzászlóaljak alakítása, mert Magyarország és Erdély újraegyesítését - amint már említettük - csak későbob, május 30-ân mondta ki az erdélyi országgyülés Kolozsvárt. A székelység igénybevétele azonban már áprilisban felvetödött: ekkor Kossuth tett javaslatot a székelység megszólítására a magyar haderö kiképzésének segítésére. Batthyány miniszterelnök mẻg nem tartotta idöszerünek ezt az indítványt. De az időszerüség nem sokảig váratott magára, s ezt felismerve a miniszterelnök - bizonyosan Kossuth beleegyezésével - maga fordult 1848. május 19-ẻn a székelyekhez: küldjenek katonai alakulatokat a szegedi katonai táborba s vegyenek részt a

\footnotetext{
${ }^{75}$ Pálffy János: Magyarországi és erdélyi urak. II. Szerk. Szabó T. Attila, Kolozsvár, 1939. 81-82.
} 
közös haza védelmében. A felhívást a Gál Sándor és Klapka György tisztekböl, valamint Hajnik Károly minisztériumi tisztségviselökböl álló küldöttség vitte a Székelyfóldre. ${ }^{76}$

Amint az Gál Sándor beszámolójából kiderül, a székely katonaság kiindulását számos akadály késleltette mind Anton Puchner tábornok, mind az erdélyi magyar politika részéröl. Utóbbival kapcsolatban Gál Sándor kủlönösen Wesselényi Miklósnak a székelyekhez intézett felhívását emelte ki, amely határozottan kérte a székelyektől: „a szegedi táborba ne induljanak, mert Erdélyt is veszély fenyegeti" S mivel Wesselényi a székelyek körében nagy népszerüségnek örvend, felhívásának a következményei súlyosak lehetnek. ${ }^{77}$

Minden akadályozó tényező ellenére, a háromszéki és csíki határör székelység hajlandó lett volna kiindulni a szegedi táborba, de nem a régi, Habsburg-rendszerü formában, amelyet sérelmesnek s megalázónak érzett, hanem mint új alakulat: ne csak az eddigi határörök, hanem - amint hangoztatta - „ha megyünk, együtt menjünk nemesek, katonák és jobbágyok". Csakhogy az erdélyi császári föparancsnok engedélye nélkül nem lehetett kiindulni, ezért Kézdivásárhelyen a „népgyülésből egy választmány” arra szólította fel a II. határörezred parancsnokát Dobai ezredest, hogy járjon közbe Puchnernél, tíz napon belül indítsa $\mathrm{ki}$ az ezredet „,különben ök fognak rendelkezni, mert ök nem engedik Magyarországot a veszedelemre tovább kitéve maradni; az ezredes irt is, de semmi eredménye nem lett. " 78

Emiatt nem mehettek a székely ezredek a szegedi táborba, s csak késöbb, júliusban indult el egy zászlóalj Háromszékröl, s augusztusban ugyancsak egy zászlóalj Csíkból Magyarországra. Velük tartott egy huszárosztály is.

Gál Sándornak a miniszterelnökhöz intézett jelentése kitért a korábban nem katonáskodó, adófizető marosszéki és udvarszéki szabad székelyek ügyére is. Ök már elszoktak a katonáskodástól és attól tartottak, hogy ezután adózni is kell és határör módra katonai szolgálatot is teljesíteni. Emiatt „nem igen kíván az átalakulás elveivel megbarátkozni". ${ }^{79}$ Gál azt javasolta, hogy össze kell egyeztetni az egész székelység katonáskodási rendjét, de egyelöre nem kell feloszlatni a határỏr ezredeket.

Bár Gál jelentését Batthyány miniszterelnöknek küldte, az akkori szokás szerint a közérdekủ iratokat a miniszterek mind megkapták, igy Kossuth is tudomást szerezhetett abból a székelyfóldi helyzetröl. A székely kérdés bonyolultságával azonban csak később, a pesti népképviseleti országgyülésben ismerkedett meg.

Ugyanis az 1848. május 29-én kezdödött utolsó erdélyi rendi országgyủlés a pesti népképviseleti országgyülés elé utalta azokat a kérdéseket, amelyeket nem tudott megoldani. Nos, ilyen kérdés volt a határörség ügye. A Kolozsvárt 1848. május 29.-én összeült országgyülés elvi döntést hozott: a fegyverviselő székelyek nemzetörök lesznek, az eddigi „törvénytelen katonáskodási viszonyok eltöröltetnek”, a határöri rend visszakapja polgári jogait. Ez megfelelt volna a székelység akaratának, csakhogy a III. törvénycikk 5 . paragrafusa elöírta: egyelöre a ,fegyvert viselö (effektív standbeli) székelység, mint nemzetör köteles katonai rendes fegyelem mellett katonáskodni" ${ }^{80}$ Ennek a rendszernek a további fejleményei már a magyar népképviseleti országgyülés történetéhez tartoznak.

A székely kérdés bonyolultsága a székely társadalomfejlődés sajátosságainak a következménye volt: másként alakultak az úrbérségi, a katonáskodási és az adózási

\footnotetext{
${ }^{76}$ Egyed Ákos: A magyar kormány küldöttsége a Székelyföldön 1848 tavaszán. Gál Sándor tanácsos jelentése. Historia manent. Demény Lajos-Emlékkönyv. Bukarest, 2001. 307-312.

${ }_{77}$ Gál Sándor jelentése Batthyányhoz. MOL. OHB. 454/1848/E.

${ }^{78}$ Uo.

${ }^{79}$ Uo.

${ }^{80}$ Bővebben Garda Dezső: A forradalom katonái Csikban és Gyergyóban. 184-1849. Csíkszereda, 1998. 17.
} 
viszonyok, mint az erdélyi vármegyékben, vagy pláné Magyarországon, $\mathrm{s}$ - amint említettük - az erdélyi rendi országgyülés nem tudta megfelelően kezelni ezeket a kérdéseket. Következésképpen a magyar országgyülésre hárult az a feladat, hogy a székely önkormányzati maradványok sorsáról, a közadózás bevezetéséröl, a székelyföldi jobbágyfelszabaditás végrehajtásáról s mindenekelött a határőrrendszer felszámolásáról, illetve az egységes katonai szolgálatnak székelyföldi alkalmazásáról megfelelö törvényeket alkosson.

Lássuk, mi történt az utolsó kérdést illetöen, mennyiben sikerült vagy nem sikerült a magyar politikának megfelelö törvényt alkotni a székely katonáskodásról.

A székely kérdés tárgyalása heves vitát váltott ki a népképviseleti országgyülésben 1848. augusztus elején, amelyet Kossuth Lajos figyelemmel kỉsért ẻs többszöri felszólalással próbálta a székelyek ügyét általános magyar kérdésekhez közelitve, a megoldás felé terelni.

$\mathrm{Az}$ említett vitát az az interpelláció váltotta ki, amelyet Fábián Dániel országgyülési követ terjesztett elö az alsóház 1848. augusztus elsejei ülésén. Fábián Dániel református lelkész Kézdivásárhely város követe volt, Kossuth nemzeti politikájának híve és támogatója, s többször fordult írással a székelységhez, kérve, figyelmeztetve, hogy a magyar szabadságharcban legyenek méltóak régi hírnevükhöz. ${ }^{81}$ Itt meg kell jegyeznünk, hogy a székelyeket, a Székelyföldet a magyar közvélemény nem ismerte a maga valóságában. Bözödi György, aki egyébként túlzott pesszimizmussal írt a Székely bánja címủ mủvében a székelyek történelméröl, amikor a magyar közvélemény tájékozatlanságáról szól, Kossuth kijelentésére is hivatkozik: Kossuth éppen a vita során vallotta be, hogy a kormány nem ismeri kellően az erdélyi viszonyokat.

$\mathrm{Az}$ 1848. augusztus elsejei interpellációval Fábián Dániel azt kérdezte a hadügyminisztertől: van-e tudomása a bécsi "haditanács"-nak azon "ármányos cselszövés"éről, amellyel a székely határöröket szeretné saját terveinek megnyerni. Utalt azokra a hírekre, amelyek szerint az osztrák hadügyi vezetés ${ }^{82}$ a szolgálati idö csökkentését igérte az eddigi 20-25 évről 10 évre, az invalidusok korának leszállitását 60-ról 50 évre, a hatảrőrzés napi díjának felemelését 4-ről 6 krajcárra, valamint a só árának és a papoknak járó kepeadó mérséklését. $^{83}$

A felsorolt tényekhez az interpelláló kézdivásárhelyi követ a következỏ kommentảrt füzte: "ha mindezt a bécsi haditanács csak egy fél évvel is előbb tette volna", úgy tekintené, mint annak jelét, hogy "az emberiség s a szánalom szent érzete megszállta, s ezen elnyomott szegény népen segíteni akar." Csakhogy ezt nem teheti, mert a székelység korábbi ilyen irányú kéréseit mindig elutasította. Bécs célja tehát nyilvánvaló: elejét venni annak, hogy a székely haderő a magyar nemzeti törekvések szolgálatába álljon.

A kérdezett hadügyminiszter Mészáros Lázár nem tudott kielégítő választ adni a felvetett kérdésekre. Ezért többen arra figyelmeztették a kormányt, hogy vegye komolyan Fábián Dániel interpellációját. Hont megye követe, Semberg Ignác szerint a kézdivásárhelyi követ érvei jól mutatják: a „reakció” a Székelyföldön is ,ármánykodik” a magyar törekvések ellen. Perczel Mór, a későbbi tábornok azzal érvelt Fábián Dániel mellett, hogy a magyarországi hadak vezetői is folytonos összeköttetésben vannak a bécsi hadügyminisztériummal, amely ugyanúgy viselkedik, mint a korábbi Hofkriegsrath. Súlyos

\footnotetext{
${ }^{81}$ L, Az 1848-1849. évi első népképviseleti országgyülés történeti almanachja. Szerk.: Pálmány Bẻla. Bp. 2002. 2040-242.

${ }^{82}$ Ekkor már formailag a haditanács nem mủködött, feladatát a hadügyminisztérium vette át, de azt a tervezetet, melyrỏl a vita folyt, valószínủ korábban a haditanács fogalmazta meg,

${ }^{83}$ A felszólalásokat közli a Kossuth Hirlapja 1848, augusztus 3-i, 29. száma.
} 
vádakkal illette Vay Miklós erdélyi királyi biztost is, aki nem tett me'g mindent azért, hogy Erdélyben érvényt szerezzen a magyar törvényeknek. ${ }^{84}$

A vita során Kossuth többször is szót kért: elöször is kijelentette. hogy a bécsi kormánytól senki sem fogadhat el utasítást $s$ aki mégis ilyet tesz, azt hazaárulónak fogja tekinteni. Aztán nyomban a székelyek ügyére tért ki. ${ }^{85}$

Kossuth kérte, hogy az erdélyi követek lehetőleg gyorsan járjanak el feladatuk teljesítésében, s mert a székelyek ügyénél "semmi sem fekszik inkább" a lelkén, bárki tehát elöterjeszthet olyan törvényjavaslatot, amely mindenkinek jó, de mégis a székelyeket tartotta arra hivatottaknak, hogy saját ügyeikben intézkedjenek. Ezeket mondotta: "Bárki részéröl történik indítvány, mi benne jó van, mindnyájunk érdeme lesz egyaránt. $S$ felszólitom a székely követ urakat, kik a székely viszonyokról kétség kívül jobban vannak tájékozva, mint a ministérium tagjai [...] méltóztassanak magukat az illetö ministerekkel érintkezésbe tenni s initiáljanak olly törvényt, melly a székely nemzet megnyugtatására egyrészröl, de más részröl azon biztosság fenntartására is szolgáljon, melly a székely nemzet hazafiúságának alapjára fektetve a közös haza érdekében áll."

Vagyis olyan törvényt kellett Kossuth szerint alkotni a székely katonaságról, hogy az mind a székelység, mind a közös hazának megfeleljen.

Aztán Bécshez intézte szavait: „a bécsi hadügyminisztertöl vagy bécsi ministeriumtól akarnók kérdezni, hogy micsoda engedményeket akar adni? Hiszen könnyü engedményeket adni máséból, ez olcsó liberalismus volna. Nem tetszett egy sebet is meggyógyitani, addig mig hatalmukban állott, már most meghiszem, hogy szórni akarják Magyarország feloszlását, dissolutióját ajándékképpen. Mi latra fogjuk vetni a haza körülményeit, igazságot adunk mindenkinek, de privát érdekért a hazát veszélyeztetni nem fogjuk. Initiáljanak tehát törvényt azok, kik a körülményekbe avatva vannak, minél elöbb, $s$ végezzünk. "86

Kossuth tehát sürgette a székely törvény megalkotását a határöri rend megnyugtatására, s ezt kérték az augusztus elsejei vitában még felszólaló erdélyi követek: Mikó Mihály gyergyói, valamint Teleki Domokos Küküllö megyei követ is. Utóbbi a székely sérelmek sietős orvoslását azért ajánlotta a kẻpviselőház figyelmébe, nehogy mások megelözzék a magyar országgyủlést. A „mások” tudvavalóan a bécsi hadügyek irảnyítói voltak. Ugyanakkor arról is szólt Teleki Domokos, hogy a székelység folytonos dicsérése inkább árt, mint használ az ügynek. Kemény Dénes viszont azt kérte, hogy a székely határörség ügyét bízzák az unióbizottságra. A javaslat elfogadásával a kérdés egyelöre lekerült az országgyủlés napirendjéről. Valóban, az unióbizottságban Berde Mózes háromszéki követ már a következỏ nap, augusztus 2-án ismertette a kérdésre vonatkozó törvényjavaslatot, amelyet aztán 5-én a népképviselő ház elé terjesztett. Erre még visszatérünk, elöbb azonban lássuk, mit írt a székely problẻmáról a Kossuth Hirlapja.

Kossuth szerette volna minél jobban megismerni az annyi problémát okozó székely katonáskodási rendszert, $s$ így képes volt a dolog lényegének $s$ a teendőknek a felvázolására. Az irás - nagy valószínüséggel mondható - Kossuth kérésére készült; erre vallanak a körülmények, ezért is legyen szabad bövebben kitẻrni rá. ${ }^{87}$

A szerző abból indult ki, hogy a határőri rendszer mintegy 120000 fỏre terjedt ki, Aranyosszéket nem számítva, majd a terheket ismertette: 1. A rendszer a székely ifjakat gátolta a közép és felsőbbiskolai tanulásban; 2. a székely birtoktulajdont a fegyverviselés alapjává tették; 3. a katonaiskolában „csak a katonai függés szabályait” tanították, de „a

${ }^{84}$ L. Az 1848-1849. évi elsõ népképviseleti országgyunlés történeti almanachja. Szerk. Pálmány Béla, Budapest, 2002. 240-242.

${ }^{85}$ KLÖM. 11. 659. Kossuth Hirlapja, 1848. augusztus 3. 29. sz.

${ }^{86}$ Uo.

${ }^{87}$ Bialis Ferenc: Székely Ügy. Kossuth Hírlapja, 1848. augusztus 4. 30. sz. 
polgári élet iránti vonzalom még csirájában elfojtatott a zsenge fiatalság keblében, sôt a nemzetiség, alkotmányosság elfojtása is eszközöltetett"; 4. a katonaiskolát végzett székely ifjakat idegen tisztek alkalmazása által háttérbe szorították; 5. adóssági, gyámsági, rendörségi ügyekben katonai ítélöszék alá tartoznak a határörrendüek, sőt Csíkszékben a falusi szabad bírák, esküdtek kinevezését és meghiteltetését (eskületételét) a katonai hatalom magához ragadta. A szabadságvesztés olyan fokú volt, hogy a fegyverviselő székelységet a szabadságnak még csak az eszméjétöl is távol tartottảk.

Konkrétabban szólva: a mintegy 19000 gyalogos, tényleges fegyveres székely a tavaszi, öszi és téli fegyvergyakorlaton vett részt, határörzést, örszolgảlatot teljesített; a 2000 huszár katonai szolgálata évente 50 napot vett igénybe. Tegyulk hozzá: ennél nem volt kevesebb a gyalogosoké sem. Vagyis a háromszéki és csíki határörkatonák, akik foglalkozás szerint nagyrészt földmüvesek, kisebb részt kisiparosok voltak, legkevesebb 50 napon nem végezhették a termelői, családfenntartói munkájukat, pedig emellett a ruházatukat is maguk állították elö; a csíkiakat ebben a „revendikált” havasok jövedelméböl kárpótolták, viszont ingyenes fahordásra kényszeríttették a tisztek számára.

A határöri rendü férfiakat gyakorlatilag egész életre szóló 18-60 év között rendes (effektív) szolgálatra kötelezték. A székelyek tudatában voltak helyzetük súlyosságának $\mathrm{s}$ azt sem feledték el, hogy idegen hatalom kényszerítette rảjuk ezt a rendszert, ezért a forradalmat jó alkalomnak tartották arra, hogy felszabaduljanak. Föleg ez kötötte le a székelység figyelmét, $s$ emiatt az egész magyar nemzetet fenyegető veszélyre eleinte a nép maga kevésbé volt fogékony.

Bialis itt következő sorai magyarázatul szolgálnak arra vonatkozólag is, hogy miẻrt késlekedett a székelység a szegedi katonai táborba való kivonulással. Mivel ez az írás a Kossuth Hirlap-jában jelent meg, $\mathrm{s}$ - amint már szóltunk róla - feltehetően Kossuth Lajos kívảnságára íródott, több mint feltevés, hogy a cikket ő maga is elolvasta. Különösen érdekesnek s lényeget kifejezőnek tartjuk az irás itt következő elemzői részét.

A forradalom kitörése után - írja Bialis - a Székelyföldön szolgáló idegen tisztek erős agitációt indítottak „Erdélynek Magyarhonnali egyesülését, minden kimondható utakon és módokon gátolni, a megbukott régi rendszert féltendỏvé vált hivatali állomások szilárdítása végett visszabüvölni; $\mathbf{s}$ minthogy törekvéseikben tekintélyes helyekröl kinyủjtott gyámkezekre találtak, egyelöre gazdag gyümölcsét aratták törekvéseiknek." ${ }^{88}$

Közbevetőleg, emlékeztetőül utalunk a már felvázolt eseményekre. Egyrészt a General Commando és tisztikara azt hirdette, hogy a magyar kormány nem illetékes rendelkezni az ügyeiben, másrészt - amint korábban már szóltunk róla - Wesselényi Miklós és többen mások, miközben a magyar ügy felkarolását kérték a székelyektől, a fegyveres székelyeket otthonmaradásra biztatták, holott azokban a hetekben Batthyảny miniszterelnök küldöttsége a szegedi táborba hívta öket. Érthetö, hogy az egyszerủ székely nem tudta, hogy kire hallgasson, zavarban volt. Emiatt tétovázott $\mathrm{s}$ késlekedett eleget tenni Batthyány felhivásának, mert elsősorban az foglalkoztatta, hogy a régi osztrảk rendszerủ katonai szolgálattól megszabaduljon. Erre ösztönözte sajảt helyzete, egyéni szabadságvảgya. Ezt a zavarossággal telített állapotot ragadta meg a Kossuth Hirlapjában Bialis Ferenc. Legyen szabad hosszabban idéznem sorait: „Midőn a fôld minden nẻpei igyekeztek a több százados rabszolgaság bilincsiböl kivergödni, a székelységre is hatott az, $\mathrm{s}$ fogékonyabbá vált a minden oldalróli bujtogatások iránt. Mintegy feljogosítva hívẻ magát, azon terhektől és sérelmektöl, mellyeknek huzamos idö óta vala igảja alatt, önerejüleg menekülni. És igy katonai kötelességeit, mellyeknek igazságtalan és törvénytelen volta irảnt egy pillanatig sem kételkedék, csak vontatva teljesitette, s teljesiti jelenleg is. S ki hinné, hogy azon harcias szellemü népfajt, melly a hon boldogságáért, éltét, vagyonát, vẻrét felảldozni legdicsőbb

${ }^{88}$ Kossuth Hirlapja, 1848. augusztus 4. 30. sz. 
hivatásának ismeré, mostan, midőn a fegyverrel megtámadott hon, a hajdaniaknál közvetlenebb s nagyobb veszélyben forog, csak nagy bajjal, rábeszéléssel lehetett az aldunai vidékeken ellenünk fegyverre kelt rácok, illyrek legyőzésére Szegedre kiszállítani."

Tehát, a székely határőr meg volt győződve arról, hogy a katonai szolgálata a régi formában igazságtalan és törvénytelen s attól megszabadulni, akár „önerejüleg menekülni”, „,bilincseiből kivergödni [...] mintegy feljogosítva hivé magát."

Aztán a helyzet ellentmondásosságát is leírva, őszintén megvallja a szerző a Kossuth Hírlapjában: bár ,a szabadság és jogegyenlöség elveit törvényben kimondottuk, az eddigi úrbéres osztályt ezeknek élvezetébe be is vezettük, s hazánk mostani körülményei nem engedik, hogy az atyafiság magasztos érzetével egyszersmind átkaroljuk a székelységet, nem engedték, hogy vállakról az annyira igazságtalan, mint törvénytelen katonáskodás terheit levegyük."

Világos: a katonaszékelynek mindenképpen igaza volt, de az ország helyzete nem engedte meg az arra illetékes vezetőknek, hogy igazságosak legyenek, mert ,gyakorlott fegyveres eröre van szükség, hogy elleneink vészes törekvéseit meghiusítsuk."

Ennek ellenére Bialis úgy látta: nem lehet más alternatíva, mint az eddigi törvénytelen katonai rendszer megszüntetése $s$ a kérdés rendezése a polgári jogegyenlöség alapján. Tévedés lenne azt gondolni, hogy Bialis véleménye a Kossuth Hirlapjában elszigetelt, nem általános közvéleményt fejezett ki. Ugyanis, valószínüleg tőle fúggetlenül a háromszéki Berde Mózes az unióbizottságban elöterjesztett törvényjavaslatának indoklásában teljesen azonos nézeteket hangoztatott, mint az előbb ismertetett szerző.

Berde kifejtette: törvényjavaslatának, amely a fennálló katonai rendszer megszüntetését írja elő "alkotmányos alapja": "Egyenlőség jogban és kötelezettségben. Egyenlő igazság mindenkinek. Ennél többet, ennél kevesebbet a katonáskodó székely magának nem óhajt." A beadvány hátán olvasható: "Én is pártolom (ti. a beadványt) Demeter József sepsiszentgyörgyi követ." 90

Berde javaslata augusztus 4-én az országgyülés elé került a véderövita során. Ez így hangzott: Törvényjavaslat a katonáskodó székelyekröl.

1.§ A katonáskodó székelyek között jelenleg fennálló törvénytelen katonảskodási rendszer, és ebböl felmerült sérelmes viszonyok jelen törvény ereje által eltöröltetnek.

2.§ Az 1848-i XXII. és a honvédelem tárgyában alkotandó, és a fegyveres erejérỏl szóló törvény reájuk is kiterjesztetik, és ezeknek értelmében az egyenlöség alapján, mint az ország más polgárai, úgy katonáskodni köteleztetnek.

$3 . \S$ E törvény haladéktalanul leendő alkalmazására a ministerium felhatalmaztatik.

A törvényjavaslat pontosan kifejezte a határőri rend akaratát, $s$ Berde az országgyülésben elvileg is alátámasztotta azt: az egyesült Magyarországon más katonáskodási rendszer mint magyar, nem lehetséges.

Berde határozott igényt támasztott a határơrök felszabadítása iránt a magyar országgyülésben. "Erdély, midőn Magyarországgal egyesült, minden polgárát felszabadította, kimondta, hogy szabad a föld, szabad a személy. És uraim, a székely katonaságot úgy hozta át magával, mint rabigába füzőtt népet." A székely nép reméli, hogy a magyar törvényhozás igazságos döntést hoz.

Berde után Kossuth fejtette ki ismételten álláspontját. Mindenekelött megvallotta: "Kijelentém már több ízben, hogy az egyesült hazában nem lehet ember, ki a székelység iránt több igazi testvéri szeretetet, tőbb rokonszenvet érezne, mint én és annak állapotjáról nem privilégiumok, hanem közös jog és szabadság alapján, $s$ a közös jog és szabadsággal

${ }^{89} \mathrm{Az}$ Erdélyi Múzeum-Egyesưlet levéltára a KvÁlvt-ban. Az unióbizottság iratai. L. még Országgyülési Irományjegyzék. i.m.

${ }^{90}$ Uo. 
összekötött terhek alapján intézkedni a legkedvesebb kötelességeim közé számítom." De Berdének s más székely követnek azon határozott álláspontjával, hogy elöbb orvosolják a sérelmeket $\mathrm{s}$ aztán hozzanak általános törvényeket, nem tudott egyetérteni. "Emez indítványra nézve mindazonáltal más a nézetem, minthogy ezáltal sérelmek orvoslására akart behozni törvényjavaslatot a követ ủr. Ugyan kérem, ne sérelmeket orvosoljunk, hanem jogot alapítsunk." A székely határörség eltörléséről határozott álláspontja volt Kossuthnak: a most felhozott kérdés, hogy ti. "a fegyverviselésre kényszerítö törvény törültessék el," azt kérdezi: "akkor majd mire megyünk? Hiszen könnyü azt mondani, hogy például az ösiség is törültessék el; hanem az a kérdés: mi állítassék helyébe?" A székely követektöl "egy egészen kimerítö törvényjavaslatot" vár, mert csak akkor lehet elintézni a székely ügyet."

A határör katonaság ügyét tehát Kossuth összeköti más székely kérdésekkel. Úgy véljük: tudni akarta, hogy ha a székely ezredeket felosztják, mit állítanak a helyükre. Valószinü Kossuthot is meggyözték az erdélyi (nem a székely) követek, hogy a székely határörségre Erdély súlyosbodó helyzete miatt még szükség van. A határörség megtartása mellett szállt síkra a még mindig fennálló Gubernium is, amely nem szeretett volna szembehelyezkedni Anton Puchner tábornokkal, az erdélyi General Commando föparancsnokával, aki ragaszkodott a határörség változatlan fenntartásához. Itt jegyezzük meg: az erdélyi Gubernium még mindig abban a tévhitben élt, hogy a tábornok végszükség esetében megvédi Erdély belsö rendjét, mint késöbb kiderült, - végzetes tévedés volt.

Kossuth felhívására ifj. gróf Bethlen János Udvarhelyszék követe, az unióbizottság tagja azt válaszolta, hogy már elkészült az unióbizottság javaslata a székely kérdés általános rendezéséröl, amelyet átnyújtottak a kormánynak. Kossuth a bejelentést látszólag megnyugvással vette tudomásul, de azt is látta, hogy a javaslat törvényeröre emelése még sokáig késhet, emiatt sajátos megoldást fogadtatott el a minisztertanácsban a székely katonáskodás kérdéséröl.

\section{Kossuth és a székely könnyülovas haderő létrehozása}

Kossuth elöször a székely jobbágy, főként zsellérkérdés megoldására tett javaslatot, amelyben a magyarországi lakatlan kincstári pusztákra telepítették volna a földnélküli székely zselléreket. Aztán a császári hadügyektől teljesen független székely haderő megszervezését kezdeményezte. Ez egyelöre nem jelentette a korábbi határőrség megszüntetését, de Kossuth a haza védelmének ügyét már mindennél fontosabbnak tartotta. Ne feledjük: ekkorra nyilvánvalóvá vált, hogy Bécs nem nyugodott bele Magyarország önállósodásának erösödésébe, $\mathrm{s}$ egy magyarellenes szövetség alakításán dolgozott. A védelem szervezése mindennél sủrgetöbb feladat volt.

Kossuth már júniusban szeretett volna jogot kapni katonai alakulat szervezésére, de akkor Batthyány miniszterelnök nem tartotta időszerünek az ajánlatot. ${ }^{92}$ Augusztusban azonban Kossuthtal együtt hoztak határozatot a honvédelem erősitésére. Ennek egyik legfontosabb eseménye az újoncozás megkezdése volt, amelyet Erdélyre is ki kellett terjeszteni. De Erdélyben a magyar haderő szervezése csak az unió után kezdődhetett el. Erdély és Magyarország egyesülését - mint ismeretes - május 30-án mondta ki a kolozsvári országgyülés; ezt a király június 10-én erösítette mèg. Erdélyben négy honvédzászlóalj alakítását rendelték el, de ebbỏl csak kettöt sikerült létrehozni: a XI. honvédzászlóaljat

91 Beszámoló a képviselőház 1848. augusztus 4.-i üléséröl. = Közlöny, 1848. augusztus 7. 59、 sz: Kossuth Hírlapja, 1848. augusztus 9. 34. sz.

92 Urbán Aladár: $A$ székely katonaság segitségül hivása 1848. májusában. = Hadtörténeti Közlemények 1980. 405-420 
Kolozsvárt, a XII-et Marosvásárhelyt szervezték meg. Ezzel majdnem egyidöben gróf Mikes Kelemen és gróf Bethlen Gergely toborzott lovascsapatot Kolozsvár székhellyel, aztán Berzenczey László marosszéki képviselö kapott megbízatást Kossuthtól egy erdélyi könnyülovas alakulat megszervezésére Marosvásárhely központtal.

Közbevetve: e tanulmány nem tér ki részletesen azokra a kérdésekre, amelyeket közölt tanulmányaim tárgyalnak ${ }^{97}$; itt az újabb kutatásaim alapjản a szervezỏmunkának olyan aspektusait ismertetem, amelyeket korábban csak érintettem. Természetesen az összefüggések megértése érdekében szólni kell vázlatosan a kérdés ismertebb vonatkozásairól is. Így Kossuth és Berzenczey László viszonyáról. Ez a kérdés azért is megkerülhetetlen, mert a magyar szabadságharc vezetőjét sokan megvảdolták azzal, hogy nem tudta jól megválogatni a munkatársait, s ezt Berzenczeyvel kapcsolatosan Pálffy János sokat idézett könyvében a lehető legélesebben kifejezte. Lássuk ki volt Berzenczey László, akit Kossuth bizalmába fogadott $s$ országos jelentősẻgủ feladatok megvalósításával bizott meg.

Berzenczey László Kolozsvárt született 1820-ban, apja középbirtokos volt Marosszéken. Jogot tanult; 1842-ben kapcsolódott be az erdélyi reformmozgalomba. Az 1846/47. évi kolozsvári országgyülésen Marosszék követe volt, s itt választották meg az 1848. évi kolozsvári utolsó rendi, valamint a pesti elsö népkẻpviseleti orszảggyủlésbe. A pesti országgyülésben a bemutatkozó beszéde július 11 -ẻn hangzott el, amikor Kossuth megajánlási beszédét helyeselte, s kijelentette, hogy a haza megmentése számára mindennél fontosabb. Valószínủ Kossuth ekkor figyelt fel rá, ő pedig Kossuth feltẻtlen hive lett.

1848 júliusában Kossuth megbizta a székely szegényrétegek kitelepítésének megszervezésével a magyarországi kincstári birtokokra, majd kormánybiztosi minöségben az erdélyi könnyülovas sereg létrehozására kapott felhatalmazást.

Kormánybiztosi megbízatásával kapcsolatban elsőként két kérdés vetődik fel: elöször, hogy kitöl kapta a feladatot, másodszor pedig hogy az egész Erdélyre vagy csak a Székelyföldre vonatkozott-e. Ugyanis - amint kẻsőbb látni fogjuk - Berzenczey mủködẻse körül később éles ellentétek nyilvánultak meg Kossuth és Batthyảny között.

Az első és második kérdéssel kapcsolatban idézzük Kossuth 1848. augusztus 17-én Berzenczeynek küldött átiratát. İme:

\section{"Berzenczey László - marosszéki képviseló úrnak}

A ministeri tanács által, egy önkéntes szabad könnyủ lovas seregnek Erdélyben $s$ fôkép a harcias derék székelység körében toborzảs útjáni kiảllitảsára felhatalmaztatva, Ön mint már a székely települések ügyében különben is kinevezett Ministeri biztosomat, ezennel az elöl nevezett ügyben is kormány biztosul kinevezem... "9t

A tervezett sereg létszámát Kossuth 1000-3000 föben határozta meg - „egyelöre”, ami azt jelentette, hogy ezt a számot idővel növelni szerette volna. A haderőt gyorsan ki kellett állítani s felszerelni.

Nem vitás: Berzenczey a megbízatást Kossuthtól kapta, viszont bizonytalanságot látunk a területet illetően. Illetékessége Erdélyre, de fỏkẻpp mégis a Székelyföldre vonatkozott, s ebből - látni fogjuk - erős összetủzés származik majd közte és más hadvezetők között. Mégsem mondhatjuk minden további nélkül azt, hogy emiatt Kossuth is felelős volt, ugyanis öt a minisztertanács hatalmazta fel, valószínüleg ugyanilyen illetékességi kört jelölve ki számára.

Kossuth augusztus 18-án értesítette Vay Miklós erdélyi fökormánybiztost Berzenczey kinevezéséröl: „A fennforgó körülmények által indíttatva találta magát a

${ }^{93}$ Egyed Ákos: Kossuth és a székelyek 1848-ban. = Századok, 1994. 5. sz. 831-871.

${ }^{94}$ KLÖM. XII. Kossuth Lajos, 1848-1849-ben II. 735. Újraközölve 1848-1849. Marosszék. Szerk.: Pál-Antal Sándor. Székelyudvarhely, 2001. 215. 
ministerium önkéntes szabad csapatok felállitásáról gondoskodni. A dolog végrehajtása körüli intézkedésekkel én vagyok megbizva. Egyikét ezen szabad csapatoknak (mellyeket a honvédség zászlóaljakkal nem kell egybetéveszteni) Erdélyben, különösen pedig a derék és harcias székelységböl óhajtom kiállítani. E végett tegnapi napon kelt rendelvényem mellett Berzenczey László marosszéki követ urat kormánybiztosul neveztem ki. "95

A kinevezés törvényességéhez tehát kétség nem fér: Kossuth a magyar kormány legfelsőbb erdélyi megbízottjának is tudtul adta, hogy ő a minisztertanács határozata alapján rendelkezési jogot kapott Erdélyre vonatkozóan, s mint ilyen Berzenczey Lászlót bízta meg az erdélyi, különösen a székely lovassereg alakításával.

Berzenczey küldetésével kapcsolatban fontosnak tartjuk Kossuth Vayhoz intézett rendeletének egyes kitételeire is utalni. Eszerint: 1. Vay Miklós köteles Berzenczeynek "minden kitelhető segélyt nyújtani"; 2 . amennyiben Berzenczey az erdélyi megyékben vagy székely székekben közgyülések összehívását tartaná szükségesnek, a megyei föispánok, a székely székek fötisztjei kötelesek azt végrehajtani. Vay kormánybiztos köteles megfelelö rendelkezéseket hozni, hogy az önkéntes szabad lovassereg kiállítása a "lehetö leggyorsabban s a lehető legnagyobb sikerrel megvalósuljon."

A fentiekből kiderül: Kossuth igyekezett körültekintően eljárni. Pontosan kijelölte Berzenczey feladatkörét $s$ helyét az erdélyi magyar vezetési struktúrában. Hogy szakmailag is jól induljon a munka, már augusztus 17-én átiratot küldött Mészáros Lázár hadügyminiszternek, amelyben arra kérte, jelölje meg pontosan, mire van szükség egy ilyen alakulat felállításához, mert "én a Kegyed utasítását akarom követni mindenben, csak a végrehajtást kérem reám bízni." ${ }^{97}$ Másként szólva: Kossuth nem szándékozott a hadszervezés szakmai kérdéseibe beavatkozni: ő a "végrehajtás" jogát igényelte. Kossuth a legkiválóbb szervezök közé tartozott, amit már bizonyított pénzügyminiszterként $s$ többek között azzal is, hogy az 1848. július 5-én megnyílt országgyülés az ő javaslatára tárgyalta első napirendi pontként a haza védelmének ügyét, $s$ ő volt az, aki a nevezetes július $11-\mathrm{i}$ beszédével megnyerte az országgyülést 200000 ủjonc s 42 millió Forint hadihitel megszavazására.

Kossuth kérését a hadügyminisztérium teljesítette, s megfelelổ szakmai utasításokkal látta el Berzenczey Lászlót is. ${ }^{98}$ Kérdés viszont, hogy a könnyü lovasságot ténylegesen szervezỏ Berzenczey mennyiben tartotta mágát à megbizatáshoz, s felelỏsẻge tudatában jảrte el mindig. Mielött azonban erről beszélnénk, legyen szabad rövid kitẻrőt tennünk azt tisztázva, vajon honnan vette Kossuth a külön székely haderő alakitásának ötletét. Vissza kell térnünk Gál Sándor 1848 . június 25 -i jelentéséhez.

Gál Sándor szerint, ha ,az organizált székely ezredeken kívül még székely eröre leend szükség", toborzás útján lehet azt kiállitani, a tiszteket pedig a székely ezredekböl kell átvenni. S minthogy a maros- és udvarhelyszékiek nem katonáskodtak, a csíkiak és háromszékiek segítségével lehetne őket is kiképezni. Gál Sándor ki korábban a kézdivásárhelyi katonaiskola professzora volt, vállalnả az ifjak kiképzését. Nos úgy vẻljük, Kossuth Lajos Gál Sándor jelentése nyomán látott hozzá a székely lovassereg szervezéséhez, aminek meggyőző bizonyítékát látom abban, hogy Berzenczey mellé katonai szakértőként Gál Sándort nevezte ki Kossuth Berzenczey javaslatára.

\footnotetext{
${ }_{95}^{95}$ MOL. F 113 Vay Miklós kormánybiztos iratai. 707/1848.

${ }^{96}$ Uo.

${ }^{97}$ Kossuth Lajos: Írások és beszédek 1848-1849-röl. Válogatott és sajtó alả rendezte Katona Tamảs. Bp., 1987. 126.

${ }_{98}^{98}$ MOL, H 21, OHB Kossuth Lajos miniszteri iratai. 25. sz. Ezt a dokumentumot Hermann Róbert bocsátotta rendelkezésemre.
} 
Berzenczey 1848. augusztus 28 -án beszámolót küldött megbízójának, ${ }^{99}$ Kossuthnak. Eszerint a Székelyföldön kedvezöen fogadták a tervezett lovassereg alakításának a hírét, $\mathrm{s}$ arra kéri, nevezzenek ki olyan katonai parancsnokot, aki "kellö minöségekkel fel van ruházva, aki ti. a három fegyvernem harcászatát (taktikáját) ösmeri, ki a stratégiai tervezeteket készíteni képes, ki a technikai mủveleteket, milyen a hidászat, utászat stb. érti, kinek statisticai ösmerete van, ki határozott, szilárd jellemü, és ki a Székely Nemzetnél oly népszerüséggel bír, mely a harcosok bizodalmáról kezeskedik, és aki végre a magyar ügyben mint igaz hazafi tiszta politikai irányú." Berzenczey szerint ilyen vezér lehetne Forró Elek, "aki valódi törzsőkös székely származású, és a fen/n/ említett tulajdonokkal felruházott egyén." 100

Forró Elek Marosvásárhelyt felállítandó központi szakértöi választmány irányitásával végezné feladatát. Gál Sándor pedig, akit szakértő-tisztként Berzenczey mellé örnagyi ranggal kér kinevezni, rövidesen elkészíti az oktatási szabályzatokat. Végül Berzenczey beszámolójából kiderül, hogy megkapta a hadügyminiszter által készitett számítást 1500 lovas kiállítására.

Berzenczey megkezdte a szervezömunkát az egész Székelyföldön, s az eredményekröl gyakran beszámolt Kossuthnak. Ezekre most nem tartjuk szükségesnek kitérni, mert máshol foglalkoztunk velük. Viszont szólnunk kell a miniszterelnökhöz, a hadügyminiszterhez intézett leveleiröl, mert azokból kiderül, hogy a szervezés során nem várt akadályokba ütközött.

A Batthyány miniszterelnöknek 1848. szeptember 20-án írt leveléböl tudjuk meg, hogy Berzenczey beutazta a Székelyföldet, s miközben a szabad lovas csapat szervezését végezte, számos akadályt okoztak a székelyföldi intézmények $s$ az, hogy ,az osztályok közti elkülönülés és gyülöltség még ki nem aludt”. A levélböl azonban kiderül, hogy Berzenczey - eredeti megbízatásán túl, ,általános felkelés” által véli eloszlathatónak „a székelyfơldi osztálykülönbségekből eredett zavarokat", mert az általános székely felkelés 30000 emberrel számolhat $\mathrm{s}$,már csak az elokkészületek is elégségesek leendenek az erdélyi oláh és szász mozgalmakat elnyomni." Tervẻhez királyi biztos kinevezése szükséges, aki pénzt és fegyvert biztosít a felkeléshez. Nem kell túlságosan meglepődnünk Berzenczey népfelkelésre vonatkozó elképzelésein, hiszen már korábban, szeptember 13-án Batthyány miniszterelnök népfelkelést hirdetett a veszélyeztetett dunántủli megyékben, amiről Berzenczey már tudomást szerezhetett. Azonban Berzenczey nem egy másik tejhatalmú biztos kiküldésére gondolt, hanem arra, hogy ö kapja majd ezt a funkciót. És ezzel már túllépte a Kossuth által kijelölt hatalmi kört, s kiváltotta ellenfeleinek fellépését.

Ugyanis teljhatalmú kormánybiztost Batthyány miniszterelnök nem nevezett ki a Székelyföldre, hanem az országgyülés egyszerre több székely követet hatalmazott fel, s bocsátott Pestről haza, hogy segítsék a széki hatóságokat, valamint Vay fökormánybiztos müködését is erősítsék. A miniszterelnöki intézkedés Berzenczey jogkörẻt, amely korảbban az egész Székelyfơldre kiterjedt, Marosszékre korlảtozta. Ez egy teljesen ủj helyzetet teremtett, $s$ majdhogy kétségbe ejtette Berzenczeyt. Kétségeivel ủjra gróf Batthyány Lajos miniszterelnökhöz fordult szeptember 28-i levelében (arról természetesen mit sem tudva, hogy az uralkodó szeptember 25 -én érvénytelenítette Batthyány második miniszterelnöki megbizatását) ezeket írta: „Ügyünk minden székely székben teljes visszhangra tanált, itt tehát oly hadi erőt lehet kifejteni, mely túlnyomóbb erö ellenében is rövid idỏ alatt mérlegbe veti magát, - csak pénz és fegyver ne hiányozzék. Én megbizásomat - a marosszéki honvédek alakittására nézve kezemre vettem, minek végrehajtása aránt annyit vagyok bátor megjegyezni, hogy a székely székekbe kirendelt biztosoknak egyetérteni és egymásnak

99 “... Miniszter Ur terve szerént egy szabad lovas sereg alakítatik "(!)

${ }^{100}$ MOL, OHB H 21 Kossuth Lajos iratai. 25. sz. 
segédkezet nyújtani elkerülhetetlen szükséges, különben a székely erő szétdaraboltatik, és nem használtatik kellö célszerüséggel. A székely erőnek egyé (!) olvasztása pedig azért szükséges, hogy a maros- és udvarhelyszéki népesség nem katonáskodva - a (korábban) katonáskodott Csík és háromszéki honvédek belé olvasztása által hadilag rövid idő alatt kiképeztethetnek, mert gyakorlott fötiszteket, altiszteket és káder gyanánti legénységet csakis a katonáskodott székelyekböl lehet alkalmazni."101

Berzenczey fent kifejtett terve a székely hadierő egyesítése és harci erejének növelés érdekében helyes elgondolás volt és teljesen összhangban állt azzal, amit Kossuth és Batthyány Magyarországon tett az ország védelmére Jellasic támadásának visszaverésére. A magyar fegyveres erö elökészítése idöszerü volt Erdélyben is, mert Urban alezredes már meghirdette a naszódi román határörezred fellépését a magyar kormány ellen, $\mathrm{s}$ a balázsfalvi harmadik román nagygyülés is összeült szeptember 14-én s néhány nap múlva 195000 román felkelöböl álló haderő megalakítását határozta el - Puchner tábornok biztatására.

Berzenczey a székely felkelés érdekében szükségesnek tartotta, hogy „, hatalma minden székely székre egyaránt kiterjedjen". Ezzel azonban nem értett egyet Vay erdélyi föbiztos, sem a Gubernium, a székely kormánybiztosok is ellene voltak. Így Berde Mózes, Demeter József, Mikó Mihály és Keller János, ifj. gróf Bethlen János, akik azt az utasítást kapták a minisztériumtól, hogy Vayt támogassák. És Batthyány egyik utolsó rendelkezésében értesítette Berzenczeyt ,folyó hó 20-án kelt jelentésére válaszolom önnek, B. Vay Miklós k/ormány/biztos úr minden erdélyi dolgokban közvetlen intézkedésre felhatalmazva és utasítva levén, az Ö rendelkezései mindenben pontosan teljesítendök."102

A miniszterelnök álláspontja, amelyet Kemény Dénes belügyminiszteri államtitkár befolyásolt, annyira felbátorította Vayt, hogy egyenesen Berzenczey eltávolítására tett kísérletet, amit azonban megakadályozott Kossuth közbelépése: Kossuth értesítette Vayt, hogy továbbra is támogatja Berzenczeyt. Kossuthban bizva s dacolva Vay és a Gubernium ellenkezésével, Berzenczey általános székely felkelést hirdetett Agyagfalvára, 1848. október 16-ra. Ezen mintegy 60 000-en vettek részt.

A Székely Nemzeti Gyülés határozatai a székelység akaratát fejezték ki: a Székelyföld minden lakója jog szerint egyenlö, a székely határörség elszakad a General Comandotól, s csak a magyar kormánynak engedelmeskedik. A korábbi terhes katonáskodási rendszer s ebből felmerült sérelmes viszonyok megszünnek. Szóltunk már arról, hogy Berzenczeyék fellépése összhangban volt azzal, amit a magyar kormány tett a haza védelmére Magyarországon. Most azt tehetjük ehhez hozzá, hogy az agyagfalvi határozatok sem álltak ellentétben Kossuth elgondolásaival. Kossuth ugyanis október 17-én arról értesítette Vayt, hogy elmozdította funkciójából Puchnert, a General Commando parancsnokát - amint láttuk Agyagfalván Berzenczeyék is kimondták az elszakadást a föparancsnoktól; Kossuth elrendelte a Gubernium feloszlatását - Berzenczeyék is ezt tették. Azonban Berzenczeyék határozatai, valamint Kossuth rendeletei alig fél hónapig voltak érvényben, mert az agyagfalvi székely katonai tábor - kezdeti sikerek után - november 5-én vereséget szenvedett és széthullt. Utána csak Háromszék őrizhette meg a kivívott szabadságát; Erdélyt Puchner hadai s a román népfelkelés vetette uralma alá. A vereségért majdnem minden magyar politikus - Kossuthot kivéve - Berzenczeyt tette felelössé.

Azt azonban a tőrtẻnetkutatásnak látnia s láttatnia kell, hogy Berzenczey bizonyosan jobban elökészítette volna a székely felkelést, ha Vay Miklóstól, a magyar kormány legfőbb erdélyi megbízottjától megkapja azt a segítséget és támogatást, amelyet Kossuth Lajos kért tőle 1848 augusztusában. És ha a magyar kormány teljesítette volna Berzenczey azon kérését, hogy a székely lovas sereg élére nevezzék ki a magyar szabadságharccal

\footnotetext{
${ }^{101}$ MOL. F 113. Vay Miklós iratai. 3. cs. 176/1848

${ }^{102}$ MOL, H2. Az 1848-49.-i Ministeriumi Levéltảr. Miniszterelnökség 9789/1848 
elkötelezett, kiváló képességü Forró Eleket, aki Agyagfalván az egész székely haderő föparancsnoka lehetett volna, a becsületes, de határozatlan, a General Commando elleni harc vezetését csak kényszerből elvállaló Sombori Sándor ezredes helyett.

Berzenczey azonban csak részben tudta teljesiteni azt a feladatot, amellyel Kossuth megbizta. A hatalmi féltékenység és a radikális lépésektöl való tartózkodó taktika, amely Vay egész müködését jellemezte, $s$ amellyel Berzenczey radikalizmusát is korlátozni kivánta, a polgárháború során megbosszulta magát. De Berzenczey lovasserege, a Kossuthhuszárság így is fontos szerepet kapott Háromszék önvédelmi harcában.

\section{Kossuth székely-politikája 1849-ben}

Amint említettük, 1848 késő őszén a császári haderỏ és a román, valamint a szász felkelő csapatok együttes támadása kiszorította Erdélyböl a gyengébb magyar fegyveres alakulatokat. A székely fegyvereken esett csorbát Háromszék sikeres önvédelmi harca ugyan részben kiküszöbölte, de azt a csalódást, amit a székelyek veresẻge okozott a magyar közvéleményben $s$ a szabadságharc vezetésében, nem tudta feledtetni. Annál inkább nem, mivel a háromszéki önvédelmi harcról, - ahol a székelység régi híréhez méltó módon állt helyt - csak megkésve, utólag szerezhetett tudomást.

Arra is csak késöbb derült fény, hogy milyen nagy szolgálatot tett a magyar szabadságharcnak Háromszék sikeres fegyveres felkelése azzal, hogy visszatérésre késztette azt a császári haderöt, amelynek eredeti parancs szerint Magyarország ellen kellett volna felvonulnia. A császáriak Magyarország megtámadására szőtt haditervét végképp Bem tábornok erdélyi hadjárata akadályozta meg, amelyből a székelység számban és bátor hozzáállással nagy mértékben kivette a részét.

Bem tábornokot - mint ismeretes - Kossuth az Országos Honvédelmi Bizottmány elnöke 1848. december elsején bỉzta meg az erdélyi hadsereg vezetésével, amelynek a feladat Erdély felszabaditása volt.

Bem tábornok rövid idỏ alatt bebizonyitotta, hogy Kossuth jól választott: december 25 -én felszabaditotta Kolozsvárt, s 1849. január 13-án bevonult Marosvásárhelyre. Bem és a székelyek szoros és sikeres együttmüködése tulajdonképpen Marosvásárhelyt kezdődött s a magyar szabadságharc végéig tartott. Bem tábornok - amint azt a magyar történetirás eléggé tisztázta - igyekezett Erdélyt a maga elképzelései szerint katonailag igazgatni s a polgári vezetést mellözni.

Alapjában véve természetesen Kossuth politikája volt a fö meghatározója az erdélyi fejleményeknek. Ez a politika 1848 végén és 1849 elején világos: 1. Erdély visszavétele az ellenséges haderőktől; 2. aztán polgárosítása az unió értelmében és 3 . a románság, $-\mathrm{s}$ távlatilag a szászok - megbékéltetése $\mathrm{s}$ megnyerése az unió ügyének. $\mathrm{E}$ célkitüzések közül $\mathrm{e}$ tanulmány csak az elsővel foglalkozik $\mathrm{s}$ abban is csak a Kossuth és a székely hadszolgálat kérdésére tér ki.

Elöre szeretnénk bocsátani: Kossuthot nem vezette bosszúvágy a nemzetiségek ellen a polgárháborús pusztitások és szörnyủ vérengzések miatt, de a bünösök törvényi felelősségrevonásától nem tekintett el. ${ }^{103}$

Erdély politikájának végrehajtását Kossuth a hadügyeket illetően Bem tábornokra, a belügyeket pedig elöbb Beöthy Ödön, majd az öt leváltó Csány László fökormánybiztosra bízta. Ennek következtében a kutatásnak a korábbinál kevesebb olyan információ áll rendelkezésére, amely közvetlenül Kossuthtól származik, de a Bemmel és Beöthyvel, 
valamint Csányval folytatott levelezésében a számukra adott rendelkezésekböl kihámozható politikájának lényege. Ez érvényes az egész történeti Erdélyre, tehát a székelyekre is.

A dolgok jobb megértése érdekében nem árt szem elött tartani: a magyar és székelymagyar katona, bárki volt egy adott idöszakban a közvetlen parancsnoka, Kossuth Lajost tartotta legföbb vezérének. Erre legyen szabad egy, de igen meggyözö példára hivatkoznunk. Beke József alezredes, a II. székely gyalogezred korábbi tisztje, Szenttamás, Schwechát $s$ számos erdélyi csata résztvevöje, a gyulafehẻrvári ostrom táborkari parancsnoka 1849. április 29-én levélben fordult Kossuthhoz, többek között azért, mert amint irta - „Ön adott e hazának életet, ơn vezeté a népet erejének öntudatára az igazságtalanságok ellen", tehát töle várta helyzetének, a magyarság sorsának jobbrafordulását is. Mindez semmiképpen sem jelenti, hogy Bem egyénisége $s$ rendelkezései, vagy Csánynak a tábornokéval gyakran ellentétes jelentései ne befolyásolták volna Kossuth koncepcióját, s ne késztették volna állásfoglalásra, beavatkozásra. Erröl különben Kovács Endre Bem József című régebbi könyvében (1952) s Kovács István l'gy élt Bem József címủ újabb kötetẻben (1998), illetve Csányról Hermann Róbert által összeállított forráskötet (Csány László kormánybiztos iratai 1848-1849), Katona Tamás tanulmánya (Csány László erdélyi kormánybiztos) böven foglalkozik.

Ezek után térjünk vissza Kossuth és a székelyek együttműködésének történetéhez.

Kossuth nem adott Bem tábornoknak közvetlenül olyan konkrét rendelkezéseket a hadszervezésre, mint korábban Berzenczeynek. De feltételezhetỏen felhívta a lengyel tábornok figyelmét a székelységben fellelhető hadipotenciálra, amelyröl korábban - egy elöbbi fejezetben láttuk - bö értesüléseket szerzett.

Bem hadseregében már az erdélyi hadjárat indításakor jelen volt néhány székely egység, nevezetesen egy háromszéki gyalogzászlóalj és egy huszár osztály a székely huszárezredböl, Kiss Sándor örnagy parancsnoksága alatt. ${ }^{104} \mathrm{~A}$ tábornoknak volt tehát alkalma közvetlenül is ismerkedni a székelyekkel. Kiss Sándor a legkiválóbb székely fötisztek egyike, késöbb a Tömösi-szoros védelmének föparancsnoka, Bem tábornok tanácsadói közé tartozott. A jól informált Jakab Elek szerint: "Bem különös rokonszenvvel viseltetik iránta, s a székelyeket legelöbb töle és róla kezdette becsülni, tanulni és szeretni." $" 105$

Bem a székely haderö újjászervezẻsére Gál Sándor ezredest nevezte ki, Gál ezredes amint emlékezünk - az agyagfalvi had táborparancsnoka volt, nem rajta múlott a hadjárat sikere. Gál azonnal munkához látott az elsö csíki határörezred mozgósítása, illetve újjászervezése által. Látható: a székely határörség kálváriája még mindig nem ért véget, mert a kiképzett s jól szervezett katonai eröhöz Bem is és Gál Sándor is ragaszkodott.

De a határörség mozgósítása mellett a székely föhadparancsnoki tisztet ellátó Gál Sándor megszakítás nélkül szervezte újoncozással az újabb zászlóaljakat az egész Székelyfôldön, amelyeket aztán folyamatosan vezényelt Bem táborába. Így a székely haderö a régi határörökből és az újoncokból alakult egységek - mintegy 37000 fö - február 19-töl, amikor az elsö nagyobb különítmény csatlakozott Bemhez, az erdélyi haderö nagyobb részét tették $\mathrm{ki}^{106}$, $\mathrm{s}$ vitézül harcoltak mind Erdély teljes felszabadításáért, mind a cári s osztrák erőkkel vívott késöbbi nagy csatákban.

A rendkivuuli következetességgel végrehajtott hadszervezéssel Gál Sándor messzemenően teljesítette a Bem által rábízott feladatot, de ennek volt negatív következménye is: a székelység ereje kimerülỏben volt. Dobozi István marosszéki kormảnybiztos szerint: „a székelyek a legkitörőbb kifakadások között panaszolták, hogy

104 Egyed Ákos: Bem és a székelyek. = Szabolcs-Szatmár-Bereg. Levéltári Évkönyv XIV. Nyiregyháza. 2000. 29-37.

${ }^{105}$ Jakab Elek: Szabadságharcunk történetéhez. Visszaemlékezések 1848-1849-re Bp. 1880. 463.

${ }^{106}$ Uo. 502 . 
egész falvaikba(n) nem maradván dologra - egy-egy tehetetlen aggokon kívül - férfiú, [...] földjük vetetlen(ek) éhen halálra kell jutniok." A polgári hatalom képviselöi arra kérték Csányt, hogy a Székelyfoldön szüntessék meg a katonai hatalmat s a polgári közigazgatást állítsák helyre.

Kossuth sokat várt a székelyek segitségétöl, de egyelöre tartózkodó volt.

A Csánynak adott 1849. január 27-i utasításában a székelyekre vonatkozóan azt írta: "Ha azt megérdemlendik, mindazon terhek, melyek e nemzeten oly régóta törvénytelenül nehezednek - mint a határörség szervitása - az országgyülés ez értelemben hozott határozatával is egybehangzólag, megszüntessenek." 107

Úgy vélem: a "ha azt megérdemlendik" - kitételt éppen az agyagfalvi haderö 1848 öszi kudarca váltotta ki Kossuthból, aki nagy reményeket táplált a Berzenczey által szervezett harci erö iránt. Az óvatosság aztán elégedetlenségbe csapott át, különösen, ha Bem tábornok sikerei idölegesen megtorpantak.

Márpedig a február 4.-i vízaknai csata után Bem válságos helyzetben volt. Kossuthnak február 17-én Csányhoz küldött sorai nem voltak hízelgök a székelyekre nézve: „Csak már egyszer azok a székelyek vagy ne ígérnének vagy tennének valamit. Bemnek minden baja onnan származik, hogy a székelyek ígéreteire bazírozta elönyomulási operatioit. Itt azon pletyka terjedt el, mintha Gál ezredes Brassónál muszkákkal verekedett volna. Bármi legyen a dologban, igen kérem országos biztos urat, hogy ez iránt, kerüljön bármibe, magának hiteles tudósítást szerezni s engem tapasztalandókról sürgetöleg tudósítani szíveskedjék." 108

Nem csak Kossuth, de az Erdélyben tartózkodó fökormánybiztos is téves információk birtokában volt, s azt jelentette felettesének, hogy Gál Sándor "nem muszkákkal, hanem muszka gúnyába öltözött oláhokkal" ütközött meg. ${ }^{109}$ Csány még március 10-én is fenntartotta téves álláspontját, de 11 -én Bem - nem kis mértékben éppen újonc székelyeivel - Nagyszebennél szétverte az orosz és osztrák védelmet, s pár nap múlva kiüzte a maradék orosz-osztrák katonaságot Erdélyböl, így kiderủlt az igazság. ${ }^{110}$ Kossuth Erdély-politikájára - különösen a szászok iránt - nem kis befolyást gyakorolt az, hogy a cári csapatok behívásában Nagyszebennek, valamint Şaguna ortodox püspöknek igen jelentős szerepe volt. Ezért is mondott ellent Bem nagylelkủ amnesztiarendeletének a szászok iránt. Itt jegyezzük meg, hogy Kossuth ezután kezdett komolyan foglalkozni az orosz beavatkozással, s próbálta kivédeni a készülödỏ újabb cári támadást - bár a Pétervár és Bécs között folyó alkudozásokról akkor még nem lehetett tudomása.

Tény viszont, hogy Gál Sándor az ütközet miatt kénytelen volt visszatérni Háromszékre, ahol jelentős védelmi eröt hagyott hảtra, majd újra elindult, ezúttal Udvarhelyszéken keresztül Medgyes felé, ahol nagyobb székely erö csatlakozott Bem nagyon megfogyatkozott s rossz helyzetben levö haderejéhez.

Lássuk ezt valamivel részletesebben.

Alig érkeztek meg a székelyek, Bem hírt kapott arról, hogy Malkowsky altábornagy bukovinai császári csapatokkal, egyesülve Urbannal Beszterce vidékén betört Erdélybe, megverte a magyar véderöt. Bem gyorsan döntött: a székelyek egy részével ellentámadást indított, kiverte az ellenséget, s visszatért Medgyesre, ahol csapatai várták. Ekkor Puchner

${ }^{107}$ Kossuth Csányhoz. 1849. január 27. Magyar Országos Levéltár $\mathrm{H}_{2}$ 1079. Kobzli KLÖM XIV. köt. II. rész. Budapest. 1913. 248-249. L. még Katona Tamás: Csány László erdélyi fökormánybiztos. = Kossuth kormánybiztosa Csány László. 1790-1849. Zalaegerszeg, 1990. 225 és köv.

${ }^{108}$ KLÖM XIV. rész. 472.

${ }^{109}$ Csány: i.m. 193.

${ }^{110}$ Gál Sándor jelentése szerint a csatában 6 székely elesett, 15 megsebesült, az ellenség veszteségét 17 halottra és 27 sebesültre becsülte. (Bereck város levéltára a sepsiszentgyörgyi Állami Levéltárban 10. csomó. 1849. febr. 5-i jelentés.) 
kezdett támadni Szeben felöl, de Bem felerösített serege állta a harcot, majd a sikeres segesvári taktikája után hirtelen Szeben ellen ment s elfoglalta a várost, majd néhány nap múlva kiüzte az ellenséget Erdély hágóin.

Ha azt a kérdést tesszük fel, hogy mit jelentett Bem számảra a székely haderỏ csatlakozása, azt válaszolhatjuk: a székelyek nélkül Malkowsky s Urban, valamint Puchner nagy valószinüséggel felmorzsolta volna Bem maroknyỉ seregét - a XI. honvédzászlóalj és a többi harcedzett magyar egységek minden hösiessége ellenére. Ez esetben indulhatott volna az ellenség Magyarország ellen.

Ezt jól tudta Bem tábornok, Csány fökormánybiztos és általuk igy tudta Kossuth is. Az erdélyi hadihelyzet kedvezö alakulásával, a székelyek kiemelkedő hadi tetteiröl értesülve, Kossuth elfeledte korábbi kételyeit $\mathrm{s}$ több alkalommal a legnagyobb elismeréssel adózott irántuk. Ami abban is tetten érhetö, hogy amikor Bem tábornagyot a bánsági hadjáratra szólitotta fel, arra figyelmeztette Csányt: Bem székelyeket is vigyen magával."'I

Kossuth közvetlenül is kifejezte elismerését. Egyik ilyen levelének tartalmát április 20-án Csány közvetítette: "Kevés, de kedves szavak a székelyekhez" cimmel. Ebben Kossuth Lajos "országkormányzó" szavait idézi: "Szent ügyünk győzelmének esetére, szent kötelességemnek ismerendem eszköze lenni annak, hogy a megmentett haza jutalmazza meg megmentőit, hogy a vitéz székely nép java, boldogsága és dicsősége, gondjaim legföbbjei közé tartozandik."

Aztán pár nap múlva, április 27-én Kossuth ủjabb, részletesebb levélben hozza tudomására Csánynak a székelyekkel kapcsolatos rendelkezéseit.

Tekintettel a levél fontos mondanivalójára, részletesen ismertetjük.

Bevezetésképpen Kossuth elismerte, hogy a "vitẻz, lelkes székely nép" a korábbi „örökös határör-katonai” kötelezettségei miatt sok terhet hordozott. S mikor a „közös szabadság”, „nemzeti szabadságunk kivivásával” tanúsitott, arra is reménykedve gondolt, hogy hazánk szabadsága kivívásával" sérelmeik elenyésznek. S mert a régi kiváltságok világa megszünt $s$ helyébe a „közös szabadság” létesült, a polgári jogokat a székelységre is ki kell terjeszteni.

Ezért a "székelység katonai szerkezetének meg kell szünni, s helyébe a polgári jognak s polgári szabadsảgnak kell lépnie."112

il MOL, OBH H2 2568/1849. L. Kossuth Lajos: Irások és beszédek 1848-1849-böl. Válogatta Katona Tamás. Budapest. 1987. 342.

112 Részletek Kossuth leveléböl: „A vitéz és lelkes székely népnek az osztrák uralkodás idejẻben a közös hazának általános sebein kívül két fổ keserves sérelme volt.

Egyik az. hogy a polgári életéböl jobbadán következtetve, katonai uralom alatt tartatott

Másik: az örökös határōr-katonáskodási kötelezettség. Igen természetesnek talảlom, ha ez fájt a székely népnek, s természetesnek. ha azon lelkes részvétben, melyet a nemzeti szabadságunk kivívásánál tanúsít, a haza szeretetén kívül ösztönul szolgảlt azon remény is, hogy hazánk szabadságának kivívásával egyetemben e méltán fájlalt sulyos sérelmeik is elenyésznek“'...]

..Hajdan kiváltságok adtak egyeseknek szabadalmakat mások felett. most a szabadalmak ideje megszủnt, $s$ a közös szabadság állott helyébe, s e szabadság természetéhez tartozik, hogy a polgári jogok mindenkire nézve sérthetetlenek maradjanak, és senki mások felett igaztalanul ne terheltessék.

A székelység katonai szerkezetének meg kell szűnni, s helyébe a polgári jognak s polgári hatóságnak kell lépni. Az örökös határỏri katonáskodás sérelmes terhének el kell enyészni s helyẻbe az ország többi lakosaival egyenlő honvédi és nemzetôri kötelességnek kell lépni.

A katonai parancsnokoknak a majdan vármegyékké alakitandó székely székek közigazgatásába nem szabad avatkozni, hanem azon székek törvényhatósági jogaiknak, melyekhez az egész polgári közigazgatás tartozik, épségben és sértetlenül fel kell tartani, mely épséghez tartozik. hogy a polgári hatóságok csak a kormánytól, vagy akit a kormány biztosa erre különösen megbíz, vehetnek parancsokat és rendeleteket. .. (KLÖM XV. 147-148). 
Bem azonban konok vezér volt, ragaszkodott a székely katonához, akit szeretett és ez forditva is igaz volt. Ezért Csány több izben is Kossuthnak jelentette: „Bem, a vén bolond csaknem az elaggott korig kiemelni rendelte a székelyeket, én már félig utána menni voltam kénytelen”. A Székelyföldet Bem „túlterhelte". Ezért Csány elengedte egy évi adójukat ${ }^{113}$, s 1849. április 27-én megismételte a Kossuthhoz írt levelében: „Napról-napra elégültebb vagyok, hogy elengedtem az adót a székelyeknek. Azokra kell alapítanod, igen tisztelt barátom, terved, egyedül. Ha Isten arra segédhetne tégedet, hogy a Székelyföldre bemehetnél, akkor Erdélyben nec portus inferi adversus te \& tui regimen". ${ }^{114}$

A szabadságharc idején azonban nem sikerült gyakorlati érvényt szerezni a székelyek katonai téren való egyenlöségének. Viszont Bem megjelenésével a General Commando hatalma megszünt, $\mathrm{s}$ a székely határörezredeket honvéd zászlóaljakká alakították át.

Magyarországi modell szerint sorszámmal látták el az eddig még ezredek szerint nyilvántartott zászlóaljakat. Az első székely gyalogezred (Csík-, Gyergyó- és Kászonszék) hét honvédzászlóaljat hozott létre, amelyböl három tartalék zászlóalj volt. A másik (háromszéki) gyalogezredből négy honvéd zászlóalj jött létre. Természetesen a határôr katonák és tisztek rangját a fekete-sárga színeket, császári jelvényeket eltávolították s a honvédség rózsáját, kardbojtját, szolgálati ơvét és más jelvényeit akkortól viselték, amikor a magyar szabadságharchoz csatlakoztak.

Az új besorolást Mészáros Lázár hadügyminiszter április 17-én rendelte el. A következő táblázat az új besorolást mutatja.

I. Határör gyalogezred

Régi zászlóalj száma

1 .

2.

3.

4.

5.

6.

7.

II. Határőr gyalogezred

1.

2.

3.

4.
Honvédzászlóalj száma

76.

77.

78.

79.

80.

81.

82.

83.

84.

85.

86.

A székely határőrezred 11. számmal honvéd huszár ezreddé alakult. Föparancsnoka Kiss Sándor ezredes volt.

Több mint egy évnek kellett tehát eltelnie ahhoz, hogy a székely határörezredek nevükben is honvédséggé alakuljanak át. De akkor sem elözetes feloszlatás által történt meg az átalakulás, hanem az átszảmozás révén. Igaz, hogy szellemük 1848 márciusától magyarrá vált, $s$ részben 1848 őszétül (az agyagfalvi gyülés után), majd 1849-ben egészében a niagyar szabadságharcban a General Commando erői s szövetségesei ellen küzdöttek.

A volt határörezredekből alakult honvéd zászlóaljakra a következőkben is nehẻz feladat várt. Természetesen a más alakulatok mellett, de mi ezekre most nem térünk ki, mert feladatunk az elöbbiek sorsának követése.

${ }^{11}$ s Csány fökormánybiztos iratai 1848-1849. szerk. Katona Tamás i.m. 291.

114 „A pokol kapui sem vesznek erỏt rajtad s hadaidon.” 
Először Bem altábornagy bánsági hadjáratára vitte magával a legalkalmasabbnak tartott zászlóaljakat. A csíki 78. zászlóaljat például, amely Vojszlovánál olyan bátran harcolt, hogy Petöfi csodálatát is kivivta. Aztán az egyesült cári-császári haderő ellen védték a kárpáti szorosokat: a 79. zászlóalj és a 82. a Törcsvárit, a 85. és 86. a Tömösi-szorost, majd együtt Háromszéket és Csikot, a 76., 83. és 84. pedig a Besztercei-havasok átjáróit. A 80. és 82. zászlóalj Segesvárra követte Bem altábornagyot; a huszárezred pedig megosztva mindenhol jelen volt.

Kossuth persze Csányra szerette volna bízni Erdély közigazgatási átszervezését, amit a fökormánybiztos meg is kezdett, de nem sikerült befejeznie, mert Kossuth visszarendelte, mivel miniszteri tárcát kapott.

Az ország kormányzóelnöke azzal is kifejezte a székelyek iránti bizalmát, hogy saját korábbi álláspontját, miszerint ágyút csak ott kell önteni, ahol a csöveket ki tudják fúrni, revidiálta, s Gábor Áronnak jelentős összeget ígért az ágyúgyár fejlesztésére.

A székelyek Kossuth iránti ragaszkodása mély volt és ezt sok formában kifejezésre juttatták. A folklór sokat idézete alakját, Sepsiszentgyörgy pedig parcellát adott a fötéren számára. A szabadságharc leverése után is várták visszatértét.

Kossuth Lajos soka foglalkozott a székelyek helyzetével. Láttuk, hogy a székelyek legnagyobb sérelme, amelyet a Habsburg-hatalom okozott, az örökös határöri-katonai teher volt, amelyet az 1848-as forradalom kitörése után a háromszéki és csíki székelység szeretett volna azonnal lerázni vállairól. Azonban Magyarország és Erdély fenyegetettsége miatt, illetve a különféle ellenség inditotta fegyveres támadások miatt, a magyar politika a székely határörezredek feloszlatását nem tartotta időszerünek.

Kossuth külön fontosságot tulajdonitott a kérdésnek, de maga sem tudta a magyar országgyülésben dülöre vinni ezt. Ezért külön székely lovas haderő alakitását kezdeményezte, amelynek megvalósitásával Berzenczey László marosszéki országgyülési követet bízta meg. A "Kossuth huszárság" szervezése azonban - a közbejött polgárháború miatt - félúton elakadt, de sok késlekedést és gondot jelentett az is, hogy Batthyány miniszterelnök és az erdélyi Gubernium, valamint Mészáros Lázár hadügyminiszter nem támogatta a kívánt mértékben Kossuth elképzeléseit a székelyek felfegyverzésében.

$\mathrm{Az}$ 1849-es évben ủj fordulatok határozták meg Kossuthnak a székely fegyveres eröhöz való viszonyát. Akkor Erdély visszafoglalásának halaszthatatlansága miatt volt szükség a székely fegyverekre, mégpedig minden eddigit meghaladó mértékben. Ezért Kossuth Bem tábornok hadszervezési rendszerét tudomásul vette, $\mathrm{s}$ mindaddig, amig Erdélyböl nem sikerült az ellenséget kiszoritani, nem korlátozta a székelység teljes katonai erejének igénybe vételét. Aztán a legnagyobb elismeréssel szólva a székelyek szerepéröl a haza védelmében, elrendelte az eddigi, különösen nagy terhet jelentö katonai szolgálati rendszer megszüntetését és a Székelyföld polgảrositását, $s$ ennek során a székelység katonáskodásának úgy kellett alakulnia, mint Magyarország más lakóinak.

Nem kétséges, Kossuth nagyra értékelte a székelység szerepét a magyar nemzet történetében, a székelyek pedig támogatták politikáját, teljes bizalommal voltak irảnta. Ennek hagyománya ma is élö örökségünk.

Áttekintettük Kossuth és Erdély viszonyát 1848-ban. Abból az axiómából indultunk $\mathrm{ki}$, hogy Kossuth Erdély-politikája európai indittatású volt, amennyiben a magyar politika legföbb céljának a nyugateurópai típusú polgári nemzet kialakulásának elősegitését tekintette. Koncepciójának szerves része volt Magyarország és Erdély uniója, $\mathrm{s}$ a fejlettebb magyarországi viszonyok alkalmazása a kisebb testvẻrországban is. Ez a felfogás - a korábbi uniós eszméktöl most eltekintve - Wesselényi Miklós politikájảnak alapelve volt, amit Kossuth irányadónak tekintett. Az 1848-1849-es forradalom és szabadságharc feltételei 
között azonban Kossuthnak osztott ki föszerepet a történelem Magyarország és Erdély újraegyesítésének megvalósitásában. Kossuth a békés, alkotmányos átalakulások híveként olyan országgyülési törvények elfogadását igyekezett elösegíteni, amelyek az uniót a polgári átalakítással kapcsolták össze. Sokat tett a jobbágyfelszabadításért, a régi rendi törvények eltörléséért, $\mathrm{s}$ a polgári szabadságjogok kiterjesztéséért a népre, miközben nem feledkezett meg a nemzetiségi kérdés rendezésének korparancsáról sem. A Jellasic támadásával kezdödött háborús viszonyok azonban hosszú idöre leseperték a törvényhozás asztaláról a már nagyrészt, vagy legalább részben kidolgozott törvényjavaslatokat. Tény azonban, hogy Kossuth terve a történeti Magyarország helyreállitására és önállóságának jelentős arányú növelésére, nem talált támogatásra az európai nagyhatalmak körében. Ezért a forradalom programja, amely nagyrészt belpolitikai volt, sikeres lehetett, de a független Magyarország programja, amely külpolitikai összefüggéseket vetett fel, megvalósíthatatlannak bizonyult. 
